Florida International University FIU Digital Commons

\title{
The persistence of memory : slavery and trauma in Tony Morrison's Beloved
}

Helena Austine

Florida International University

DOI: $10.25148 /$ etd.FI14032372

Follow this and additional works at: https://digitalcommons.fiu.edu/etd

Part of the English Language and Literature Commons

\section{Recommended Citation}

Austine, Helena, "The persistence of memory : slavery and trauma in Tony Morrison's Beloved" (2007). FIU Electronic Theses and Dissertations. 1338.

https://digitalcommons.fiu.edu/etd/1338

This work is brought to you for free and open access by the University Graduate School at FIU Digital Commons. It has been accepted for inclusion in FIU Electronic Theses and Dissertations by an authorized administrator of FIU Digital Commons. For more information, please contact dcc@fiu.edu. 
FLORIDA INTERNATIONAL UNIVERSITY

Miami, Florida

THE PERSISTENCE OF MEMORY: SLAVERY AND TRAUMA IN TONI MORRISON'S BELOVED

‘.

A thesis submitted in partial fulfillment of the

requirements for the degree of

MASTER OF ARTS

in

ENGLISH

by

Helena Austine

2007 
To: Interim Dean Mark Szuchman

College of Arts and Sciences

This thesis, written by Helena Austine, and entitled The Persistence of Memory: Slavery and Trauma in Toni Morrison's Beloved, having been approved in respect to style and intellectual content, is referred to you for judgment.

We have read this thesis and recommend that it be approved.

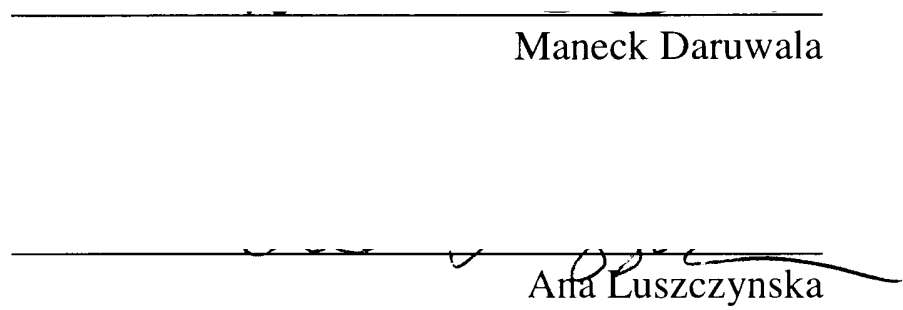

Ana Luszczynska

Heather Andrade, Major Professor

Date of Defense: September 26, 2007

The thesis of Helena Austine is approved.
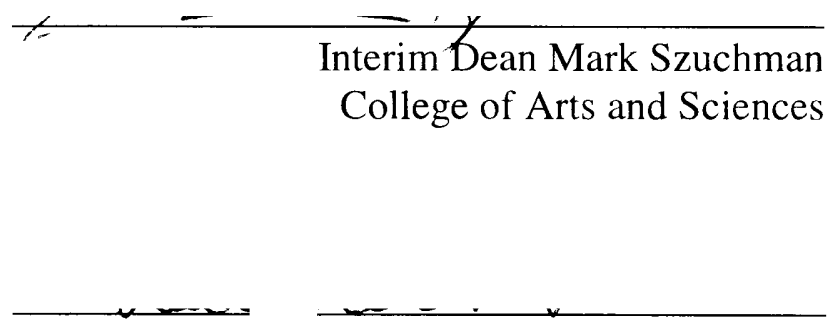

Dean George Walker

University Graduate School

Florida International University, 2007 
(C) Copyright 2007 by Helena Austine

All rights reserved. 


\section{DEDICATION}

Moyubba, Elegua, first as always, opening the roads of comprehension and connection. Moyubba, Orisa, guiding me down this path. To You all, from forge to forest, from sea to shore to mountain, to the river and the market and the cemetery, I thank You for Your many gifts, not least is the signal honor of serving You. To You, for You, in Your honor and with deepest gratitude, I dedicate this thesis. Moyubba Ochun, who directed me to follow my bliss.

To my parents, Helen and Agustin Venero, I give my deepest thanks for all their manifold support and guidance. I literally could not have done this with out you. To my grandmother, Carmela Castellanos, for all her myriad assistance, most especially during my pursuit of this degree.

Para todas mis madres conocidas y olvidadas. Moyubba Egunes.

To my daughter, Lucinda Carmen, who is a light in the world.

And to 15 million and more who bore this story: It is my privilege to offer this up, in remembrance of you. Moyubba. 


\section{ACKNOWLEDGMENTS}

First and foremost, I'd like to thank Dr. Heather Russell Andrade, for her guidance and assistance in all aspects of this work. I'd like to thank the professors of English and literature at Florida International University who have helped shape my time there so profitably. Deepest respect and gratitude to Dr. Asher Milbauer, who guided me in preparing my application to the Masters program and through my first months in the program, and throughout my time at FIU. Much gratitude to Dr. James Sutton, Dr. Ana Luszczynska, and Dr. Maneck Daruwala who all shared with me the gifts of their insights and experience, both in the classroom and out of it. In addition I'd like to thank to my colleagues in the Master's program, notably Jamie Puntumkhul, Farrin Miller, Alexandra Alessandri, Michael Portnoy and Paul Codner. Their support and kindness were invaluable to me during the completion of my course work and in teaching. Thank you all.

Leni Austine April 7, 2006 to June 9, 2007 


\title{
ABSTRACT OF THE THESIS \\ THE PERSISTENCE OF MEMORY:
}

\section{SLAVERY AND TRAUMA IN TONI MORRISON'S BELOVED}

\author{
by
}

Helena Austine

Florida International University, 2007

\author{
Miami, Florida
}

\section{Professor Heather Andrade, Major Professor}

The purpose of this study is to examine the personal narrative in the sub-genre of African-American literature known as the enslavement narrative. To do this, a deep reading of Toni Morrison's novel of slavery, Beloved (1987), will employ a psychological reading of slavery as trauma to reveal the tropes common to both the enslavement narrative and therapeutic discourses about trauma and its after effects. The personal narrative is the basis upon which the nineteenth century narrative of enslavement draws power and authority and is also of primary importance in understanding the phenomenon of psychological trauma. It is the aim of this study to examine where these two discourses overlap. By employing a deep reading of Beloved in context of psychological trauma, the African American autobiography as a literary project is found to be a means of resistance and reclamation of a whole, African American subjectivity. 


\section{TABLE OF CONTENTS}

CHAPTER

PAGE

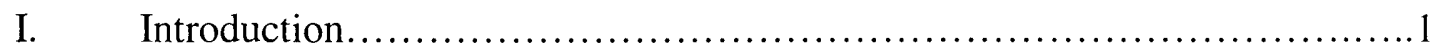

II. The Dialectic of Trauma, Enslaved Subjectivity \& the Personal Narrative........................................................ 10

III. The Persistence of Memory............................................. 39

IV. Ancestry, Displacement \& Redemption: Healing within the Community......58

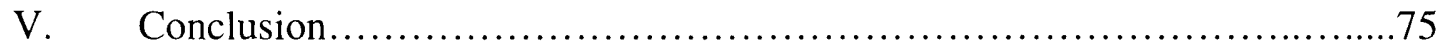

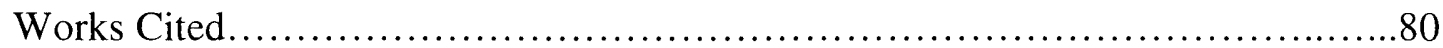




\section{CHAPTER ONE: THE NARRATIVE OF ENSLAVEMENT}

\section{AND OF LIBERATION}

The past is not dead. It's not even the past.

William Faulkner

In her novel, Beloved (1987), Toni Morrison demonstrates the devastating effects of slavery and its attendant evils as these effects manifest themselves through multiple generations of one family. The trauma of slavery is such that no one touched by it is able to break free of the past, even years after physical liberation. This is true of the novel's protagonist, Sethe, a formerly enslaved woman living in Cincinnati after the Civil War. As a young woman, while heavily pregnant with her fourth child, Sethe escaped from a life of slavery at Sweet Home, Kentucky. Upon their recapture by their sadistic owner, Schoolteacher, Sethe attempts to murder all four children, murdering her two-year-old daughter in the process, in order to spare them all the life of subjugation and violence with which she was very well acquainted.

Traumatized by the manifold atrocities of slavery (displacement, isolation, oppression, violence), Sethe's own memories are a constant source of re-injury, and her unresolved pain manifests in an anguished consciousness and a "haunted" present. The angry ghost of her murdered daughter plagues Sethe's home at 124 Bluestone Road, both signifying and perpetuating the displacement, isolation, oppression and violence of slavery into Sethe's "free" life. This ghost is metonymic, for she is not only the ghost of the individual victim, Beloved, or even of all the victims of the "peculiar institution" (as slavery was commonly called prior to the Civil War), victims whose stories have not been told; but she is metonymic of all the unhealed wounds the survivors and their 
descendants still carry. How this ghost may be laid to rest can also heal Sethe and her remaining family, and can also redeem the African-American community in Cincinnati that betrayed Sethe and her children to the slave-catchers years earlier.

Beloved represents Morrison's most ambitious narrative project, one at which she hinted in her earlier novels, particularly Song of Solomon (1977). In this novel, her attempts to inform narrative construction with history comes into its fullest expression. According to Marilyn Mobley, "although the relevance of history informs all her novels from The Bluest Eye to Tar Baby, it is in Beloved that history simultaneously becomes both theme and narrative process" (190). Its provenance is Morrison's editing of The Black Book in 1974. This compendium of Black American memorabilia chronicles the significant events, material conditions and cultural production of African Americans over 300 years in America. It was during this project that Morrison encountered a newspaper account of Margaret Garner, a fugitive slave who murdered her child at the time of their re-capture. Although Sethe's story does not follow Garner's exactly-Garner was returned to her former owner after being tried for destruction of stolen propertyMorrison does create a fiction that acknowledges and extends many tropes of the traditional narrative of enslavement, the foundational genre of the entire AfricanAmerican literary project. As such, Beloved represents the struggle for subjectivity in the face of crushing dehumanization, and the challenges of healing the psychic wounds wrought by trauma.

It is the aim of this study to examine carefully the tropes employed by Morrison in Beloved, in context of the narrative of enslavement, through the lens of a psychological reading of trauma. To do so, I will begin by defining psychological trauma 
and demonstrating how part of the healing process in trauma recovery is narrative; specifically, it requires that the survivor of trauma tell the story of their experiences. I draw comparisons between these therapeutic narratives and the enslavement narrative, and show how trauma as pathology constellates in the narrative of enslavement as a therapeutic text. I proceed, via a close reading of Beloved and other traditional enslavement narratives, to deconstruct the force of memory as a prime mover in this process, and also as the conduit by which the psychic rifts caused by trauma—rifts that run through the community/tribe and have disrupted the mechanisms of ancestry-- may be healed.

Differing thematically from Morrison's four previous novels, Beloved charts the long journey back to wholeness, as well as the necessity of bearing witness to the incidents of atrocity that have scarred the characters. In Morrison's earlier novels, we see the creation of a Cholly Breedlove, a Polly, a Sula: creatures so damaged by the violence and degradation around them that they are unable to keep from passing along that violation and shame to those they love most. In Beloved, according to Philip Page, the "emphasis shifts from external factors that create fragmentation toward internal healing processes that allow for psychic integration"(Page 133). Morrison's achievement in Beloved is to illuminate the strategies for survival and agency employed to combat a legion of trials, and to describe a (possible) trajectory towards healing and wholeness. The narratives of Sethe, Paul D, Stamp Paid and Baby Suggs bear witness to both the devastation of their lives and psyches, and to the struggle to heal them, by focusing on the more subtle psychological discourses that have perhaps eluded the historical narrative. Mobley concurs when she suggests that Beloved "exposes the unsaid of the narratives, 
the psychic subtexts that lie within and beneath the historical facts" (Mobley 193). She also locates healing and resolution as processes that must happen both individually and collectively, in order to be successful in either sphere.

Utilizing and reconstituting the tropes of the slave narrative genre, Morrison deliberately sought to give voice to those aspects of the experience of slavery that were rendered unspoken, unspeakable and unacknowledged in the traditional enslavement narrative. As she states in a 1994 interview with Angels Carabi in Belles Letres, "With Beloved, I am trying to insert this memory that was unbearable and unspeakable into the literature...There are certain things that are repressed because they are unthinkable and the only way to come free of that is to go back and deal with them...So it's kind of a healing experience" (Carabi 1).

This "unbearable" memory must be given voice and acknowledgement, or else it will rise up, unbidden, an angry ghost never at rest. Although charged with the responsibility of recording and transmitting the experience of slavery, those who created historical narratives of enslavement understood the censure they faced if they strayed into territory that they perceived their readers would deem "unthinkable" and therefore "unspeakable."

These unspeakable aspects include discourses that would have been offensive and off putting to the white, bourgeois audience to whom the traditional enslavement narrative was addressed as a form of moral instruction and propaganda. Anything related to sexuality or sexual abuse was often proscribed, or at least rationalized, as indeed was any discourse that ran counter to the dearly-held romantic notions comprising the "Cult of True Womanhood," such as female purity and the sanctity of motherhood. The reality 
of Sethe's life experience runs immediately counter to these cultural assumptions, echoing Harriet Jacob's plea in her1861 fugitive slave narrative, Incidents in the Life of a Slave Girl: “...in looking back, calmly, on the events of my life, I feel that the slave woman ought not be judged by the same standards as others" (Jacobs 48). That judgment - and the fear of it which problematizes further an already fractious discursive environment--is a salient feature in both the rhetorical construction of enslavement narratives by women, and in Sethe's continuing bereavement, via her family's ostracism. For women who wrote enslavement narratives, certain topics could not be addressed fully without risking censure from the community of readers. Even when employed as a rhetorical strategy to elicit a visceral response of pity, the distaste engendered when the formerly enslaved subject spoke of the unspeakable could backfire and ultimately alienate the bourgeois reader, rather than secure them in sympathy with the abolitionist cause. The perilous nature of breaking silence on the unspeakable is eloquently illustrated in Sethe's case. Her ostracism is a self-imposed internal exile which is symbolized by Sethe's repeating the story for "whitepeople" who make use of it, and for her daughter Denver, who rejects most of it, but being unable to complete the story she begins for Ella on the banks of the Ohio, which is her first narrative act of a liberated subjectivity. For Sethe, telling her story is an act of courage because of the great risks involved. But telling the story is as necessary a step in the reclamation of Sethe's subjectivity, as it is perilous in its consequences.

Sethe's narrative and those of her family and associates are woven together to form the text of Beloved, whose primary project is to convey the profound and lasting effects that slavery has upon the enslaved subject. Morrison uses multiple perspectives 
and narratives to great effect in all her novels. As Page notes, in Beloved the "narration is frequently subdivided among several points of view so that... while maintaining its unity, also projects a collection of perspectives" (Page 4). While in her earlier novels these multiple narratives weave together to reveal a precise and detailed vision of a community, in Beloved each of these narratives is an iteration of individual suffering as would occur within the behemoth of institutional bondage. Not content with merely documenting the material reality of slavery's legacy, Morrison employs multiple narratives so that the cumulative effect of it is, among other things, to present the aftermath of slavery as pervasive, self-reproducing and self-perpetuating into the next, non-enslaved generation.

It seems appropriate here to say a few words about the Transatlantic slave trade in order to set Beloved in its historical context, but the trade itself was such an extensive and overweening enterprise that a few words will not suffice. If the events and characters of Beloved are metonymic of slavery's various discourses as practiced in the American South in the nineteenth century, they are in fact microcosmic in view of the enormity of slavery as a cultural and political force and its impact on Atlantic culture. Operating for almost 400 years, the slave trade radically altered the destinies, geopolitics and cultures of four continents; became both the fuel and the machinery of empire; and required (at least in the US) the bloodiest of conflicts to resolve the matter of whether it is morally and legally justified to own and traffic in human flesh. Funding, in large part, the industrial revolution by providing cheap agricultural products—-thereby keeping the looms in Lowell and Liverpool busy with tons of cotton, and satisfying the enormous Euro American appetite for sugar, coffee and tobacco-the business of trading slaves 
itself was a lucrative venture upon which many dazzling fortunes were founded. Entrenched in the economics of several nations, supported through law and custom, the forced labor of millions of humans was necessary to support dizzying wealth and bourgeois enterprise, both the last vestiges of the plantation gentry and the newly evolving urban proletariat. With the fate of empires and a never-ending stream of riches at stake, the practice of slavery could not easily be eradicated.

Slavery as an institution was informed by violence and brutality at its core, and by a philosophical imperative to dehumanize the enslaved person in order to justify a range of atrocities necessary to keep him/her in line, and thereby maintain social, political and most significantly, economic order. Deprivation, cultural suppression, physical abuse, sexual exploitation, displacement of affectional ties, denial of agency and expression, witnessing brutalities committed upon others-all of these phenomena act upon the human subject in ways that impact cognition and identity. By utilizing a psychological reading of trauma, the symptomatology of slavery's long term effects in Beloved illuminates the enslaved subjectivity and rehearses possibilities for healing on an individual and a collective level.

It is the aim of this study to interrogate, via a psychological reading of trauma, Beloved's depiction of the enslaved subjectivity. The dialectic of trauma as both a psychological and political phenomenon overlaps neatly with certain canonical tropes of the enslavement narrative and African-American autobiography, notably in its privileging of the personal narrative as a modus of healing and the reclamation/reconstruction of the traumatized self. Current theories of psychological trauma are inherently political—by which I mean that these theories hold hegemonies accountable via the critique they offer 
to institutionalized forms of violence. As trauma theorist Judith Herman asserts:

"Psychological trauma is an affliction of the powerless" (Herman 33). By focusing on the human faculties most impacted by trauma and atrocity - identity, memory, and connection to community-it is possible to see these tropes manifest within the AfricanAmerican literary canon as exemplifying both the challenge to individual agency, integrity and sovereignty, and as sites of resistance and empowerment.

Through interrogating these tropes in both psychological and political-historical contexts, one finds opportunities to prevent "historical erasure or denial of those aspects which could not be easily assimilated into rhetorical discourse or into the collective (American) consciousness..." (Mobley 190). Besides the historical imperative to prevent this 'erasure', employing a psychological reading of trauma in context of the enslavement narrative opens intriguing questions related to subjectivity and storytelling up to interrogation. The critic is invited to explore 'storytelling' both materially and psychologically, as the narrative reveals itself as a healing event and a site of resistance. If the non-material effects of slavery are revealed as extensions of its material realities, then the enslavement narrative occupies a central place in generating and supporting "communities of resistance" faced with the daunting task of managing a hard won and still threatened liberty. Since part of the hard work of this liberty is healing from the past's abuses, it is by no means insignificant that both the theme and goal of many of these narratives is healing. Models for healing and reconciliation can arise out of the traumatized, dissociative milieu through the transformative process of engaging and confronting the past. While memories of the past that the many characters carry with them are not easily reconciled with their present lives in Ohio, they must engage them 
and each other to salvage their nascent alliances. They must "take advantage of this separation between past and present and the associated fragmentation to engage in extended and intensive reworkings of the past that lead toward their recoveries" (Page 133). So to must those complicit in the "Misery"-the community that has ostracized Sethe-confront their own involvement in order to redeem an unspeakable legacy of violence and horror where the distinctions between victims, perpetrators and bystanders begin to disintegrate. 
CHAPTER TWO: THE DIALECTIC OF TRAUMA,

\section{ENSLAVED SUBJECTIVITY AND THE PERSONAL NARRATIVE}

And no matter, for the sadness was at her center, the desolated center where the self that was no self made its home.

Toni Morrison, Beloved

A psychological reading of trauma and its effects on identity can be used to illuminate and to rehearse canonical tropes of enslavement narratives and their construction of Black subjectivity. What these discourses share in common is that the personal narrative is most highly privileged but also highly suspect. In employing various rhetorical strategies to plumb the depth of horrific memories and relate them 'accurately,' issues of audience, credibility and veracity immediately come to the fore. In both the narrative of enslavement and in the therapeutic context of trauma recovery and treatment, the aim of discourse is to verify and affirm the narrator's humanity, sincerity and veracity, and to provide new models for establishing the subject's agency, wholeness and connection to a larger community.

Since the nineteenth century, when Sigmund Freud began investigating the psychological phenomenon known at the time as "hysteria", psychologists have puzzled over the mysterious capacity of the human mind to literally shift out of consensus reality, and replay and re-enact incidents that are not accessible through the normal function of memory. The process of recovery from traumatic events requires the traumatized individual to break silence and tell their story. This narrative imperative is at the core of the healing process on both an individual and a collective level, and it is here that this discourse's applicability to enslavement narratives really begins to reveal itself. As 
Judith Herman states: "Folk wisdom is filled with ghosts who refuse to rest in their graves until their stories are told...Remembering and telling the truth about terrible events are prerequisites both for the restoration of social order and the healing of individual victim" (1). In purely rhetorical terms, the central trope of the enslavement narrative is that of the story that must be told but is essentially unspeakable, and is therefore so proscribed that its telling becomes the primary site of narrative tension. The trope of the unspeakable story that must be spoken is exemplified many times in enslavement narratives, as formerly enslaved narrators locate breaking the silence regarding their experiences as a vital step in reclaiming their own subjectivity.

If the personal narrative holds such a privileged space in the discourse of trauma, it is indeed significant that autobiography is the primary mode of African American literary production throughout the eighteenth and early nineteenth centuries. The enslavement narrative was a polemic tool in a propaganda war that escalated until Emancipation settled the question of slavery. As Andrews states in his essay, "The Representation of Slavery and the Rise of Afro-American Literary Realism, 1865-1920":

“...The classic antebellum slave narrative highlights the brutalizing horrors of slavery to justify forcible resistance and escape as the only way a black could preserve his or her humanity...Ultimately this objectifying power of slavery is what the antebellum slave narrative protests against most eloquently by demonstrating the evolution of a liberating subjectivity in the slave's life, up to and including the act of writing autobiography itself" (MacDowell and Rampersad 64-65). 
The "objectifying power" slavery is potent enough to severely impact the enslaved individual's sense of identity. The reclamation of that identity is a process that finds fruition in the self-definition and self-assertion inherent in telling its own story.

The objectification of human beings mentioned above was part and parcel of slavery's horrors: an aggregate of traumas that eroded the enslaved subject's sense of self. As Sethe herself described it:

“...anybody white could take your whole self for anything that came to mind. Not just work, kill, or maim you, but dirty you. Dirty you so bad you didn't like yourself anymore. Dirty you so bad you forgot who you were and couldn't think it up no more" (251).

The traumas of slavery were so dehumanizing that they could permanently alienate the victim from herself, and make it impossible for the enslaved subject to view herself other than degraded and victimized. For many formerly enslaved individuals, telling their experiences was an important step in 'thinking themselves up' again.

In both the narrative discourses of trauma and in African American autobiography, whereby literary production and therapeutic recovery overlap, it is of primary importance that only a first-person account can refute hegemonic discourses that rationalize or justify traumatizing oppression. The first step in trauma recovery is for the survivor to relate the story of the traumatizing event(s). Likewise, for many formerly enslaved persons, transmitting the story of their lives under slavery was a critical step in the formation of a non-enslaved identity. The primacy of the personal narrative is thereby acknowledged in African-American letters, and acts similarly in both historical narratives, such as Frederick Douglass' Narrative of the Life of Frederick Douglass 
(1845) and in revisionist fictions, specifically Toni Morrison's Beloved. In both these texts, the personal narrative of the formerly enslaved subject holds a position of central importance, forming the basis of the plot, informing choice and action, and providing the very means by which that subject asserts a psychological emancipation that matches its material counterpart. In short, the narrative becomes the arena in which the emancipated subjectivity creates and asserts itself.

Douglass's $\underline{\text { Narrative }}$ and Morrison's Beloved occupy respected, almost revered, niches in the African American literary canon. In invoking these texts as canonical examples of the genre, I'm consciously placing Beloved in context of enslavement narratives. Their dissimilarities reveal a range of narrative possibilities and an evolution within the canon. By placing Beloved in context of the enslavement narrative-more accurately described here as a historically revisionist or "neo-slave" narrative-what is significant is Beloved's position as an ultimate flowering of the genre, by bringing forward the full range of discursive possibilities that were nascent in the historical narrative, and giving triumphant voice to those aspects that were proscribed or suppressed.

Douglass's Narrative (1845) is foundational to the study of enslavement narratives as a whole. William McFeely, in the Norton critical edition of Douglass' Narrative, situates it critically among "the series of great 'I' narratives of that most remarkable decade of American letters" (Douglass 133), alongside those other paeans to self-emancipation: Melville's Moby Dick (1851), Thoreau's Walden (1854), and Whitman's Leaves of Grass (1855). A first-person autobiographical account of his life under and escape from slavery, and the early years of his new free identity, The Narrative 
charts Douglass' physical and mental resistance to slavery, and his ultimate reclaiming of a personal subjectivity, whose process was aided in no small part by the production of the Narrative itself. As Douglass himself asserts, the literary component of creating a postslavery subjectivity was vitally important to the project he eventually undertook. Though essentially penniless upon his arrival in New Bedford, Douglass managed to subscribe to abolitionist William Lloyd Garrison's journal, the "Liberator," which

"became my meat and my drink. My soul was set all on fire. Its sympathy for my brethren in bonds-its scathing denunciations of slaveholders-its faithful exposures of slavery—an its powerful attacks upon the upholders of the institution—sent a thrill of joy through my soul, such as I had never felt before!...I took right hold of the cause (Douglass 74)"

This was the means through which Douglass became acquainted with other abolitionists, from which he drew enormous support and encouragement. In working for the cause, he was moved to overcome his timidity and begin to speak about his journey from slave to free man. These acts of self-assertion—his act of "authorizing" himself by authoring himself-is a vital part of creating his emancipated self.

In contrast, Morrison's narrative, written some 140 years later, is a fictionalized account of a historical event. Written predominantly in the third person, Beloved is informed by narrative threads from a variety of characters, and becomes the site for deliberately giving voice to the stories that could not, for any number of reasons, be told during the antebellum and immediate post-bellum periods in the form of AfricanAmerican autobiography. The time and distance from the actual events has not effaced 
the importance of Sethe's story, which is metonymic of slavery as a whole. Indeed, our country's continual struggle over issues of race and racism, embodied in numerous conflicts over access, representation, discrimination and economic disenfranchisementproves as great a need for the facts and the narratives of slavery and its legacy to be examined than ever. By interrogating the discourses of slavery as traumatizing, and therefore self-replicating through time and space, Morrison proves, in direct opposition to her own closing statement in the novel, that the story of Beloved and the other "60 million and more" is, indeed, a story to be passed down.

Beginning where the historical narrative ends, the fictional enslavement narrative brings forward many salient aspects of the historical narrative, while opening possibilities for new readings. It explicitly questions issues of authority and audience in a manner which the historical narrator cannot, and reveals discursive 'blind spots;' for example, in the construction of the enslaved female in texts by formerly enslaved men. A gendered analysis notably absent in most Douglass criticism is offered by critics MacDowell and Foster, both of whom challenge the negation of Black female subjectivity through Douglass' emphasis on Black women as abused bodies only, thereby pointing out the masculinist bias underpinning both his work and its criticism.

Invoking the 'Sambo' myth of black emasculation-where the abuse of enslaved women is deployed primarily as source of humiliation to enslaved men-- MacDowell and Foster point out that the construction of Black enslaved women as perpetual sexual victims is more commonly reported in the narratives of enslaved men than in those written by enslaved women: According to Foster, "Unlike the male narratives, which portray graphically the sexual abuse of slave women, female narratives barely mention 
sexual experiences and never present rape or seduction as the most profound aspect of their existence" (Douglass 176). Invoking Freud and feminist semiotics, MacDowell points out that: “...with perhaps the exception of his mother and grandmother, slave women operate almost totally as physical bodies, as sexual victims...(176)" and further suggests that the sexual undercurrent of male narratives of enslavement encode and reproduce a negation of black women's bodies (and selves) that is consistent with gender discourses within the dominant white hegemony, another instance of Douglass copying out "master Tommy's copybook" perfectly.

Certainly Douglass' Narrative contains many graphic descriptions of physical abuse heaped upon black female bodies, which at first are identified by name or relationship (his aunt, his grandmother, his wife's cousin) but at last are nameless and totally objectified, the important view point being that of Douglass as voyeur. More disturbing to the reader is the possibility that these discourses are presented as compelling evidence of slavery's dehumanizing affects only inasmuch they impact Douglass' emergent subjectivity, without alluding to the effects upon the women so victimized. If narrating his experiences of slavery is foundational to Douglass' emancipated subjectivity, then it becomes a discursive trap critically, because "to explain the repetitions of whippings solely in rhetorical terms and in the interest of Douglass' selfexpression leads to some troubling elisions and rationalizations, most troubling being the black woman's body. In other words, Douglass's "freedom"-narrative and physical alike—depends on narrating black woman's bondage" (Douglass 177). This process of elision begins when Douglass informs us he barely remembers his mother, and it continues throughout as women identified as his kin come briefly into focus and then 
disappear. Of the free wife with whom he begins his new emancipated life in New Bedford, we hear very little, although he offers up his marriage license in the text as a proof of his legal and psychic enfranchisement: no longer chattel, he can now be party to contracts. It is true that Douglass recognized the connection between the civil rights struggles of women and those of African-Americans, was a passionate activist for women's suffrage, and indeed was the only man present at the 1848 Seneca Falls suffrage conference. This does not change the fact that no mention is made, by either Douglass or in his criticism, that according the laws of the nineteenth century, he holds a legal authority over his wife's person (and her labor!) akin to the slavery he just evaded.

It is to be expected, then, that gender should be a site of narrative tension, considering the brutal ways gender, reproduction and sexuality manifest within the discourse of slavery. In the historical narrative, the risk taken in relating the unwelcome and unpleasant facts about slavery to a white readership was significant. Given that gender and sexuality as topics of discussion were already heavily proscribed within the dominant discursive paradigm, it is understandable that formerly enslaved writers would choose to exercise a certain amount of discretion or manipulation when elucidating these parts of their histories. The writers justify actions outside the moral code of their bourgeois readers by invoking slavery's dehumanizing effects, or they obfuscate their own experiences with the observed abuse of others, thereby displacing themselves away from "degradation" and giving their white reader a more comforting distance. In the revisionist narrative, strategies deployed against the objectification of the enslaved individual become privileged within the text as a mode of (re)creating and fostering subjectivity. Hazel Carby in "Ideologies of Black Folk: The Historical Novel of 
Slavery" offers up an analysis of this phenomenon, and posits its impact on modes of resistance and agency:

"It is well known that the majority of published slave narratives were written by black men...From this statistic we can conclude, not surprisingly, that as autobiography, and, as history, they are narratives of his-story. When black women figure in these narratives, it is largely as victims of sexual abuse. In this light it is significant that the majority of contemporary novels about slavery have been written by black women. Moreover it might be argued that these novels posit a female-gendered subjectivity, more complex in dimension, that dramatizes not what was done to women, but what they did with what was done to them" (MacDowell and Rampersad 146).

It could be said that gender forms one of the lines along which the enslavement narrative has evolved: that movement from the historical to the post-bellum, fictional narrative is evident not only in more woman-produced texts, but in a construction of Black subjectivity with a greater emphasis on how agency, autonomy, resistance and selfemancipation manifest in a milieu of crushing violation and violence. The salient feature of the revisionist text is how the enslaved subject transcends his/her victimization, and how women's agency in resistance and rebellion in this regard becomes a potent site of interrogation.

Despite dissimilarities in style (non-fiction v. fiction, first hand v. third person) and author's positionality (male v. female, then v. now, enslaved v. free), what both 
Douglass and Morrison hold in common is their eloquent portrayal of the trauma attending to atrocity, and the effects of slavery upon the traumatized subjectivity. The saliency of a psychological reading of trauma on literary discourse has recently been interrogated with regard to the so-called literature of atrocity, constituted for the most part by texts centered on the Holocaust. Interrogating traditional and revisionist narratives of enslavement within this sphere of discourse requires a certain amount of theoretical 'place-setting.' The aim of this chapter is to provide a rudimentary comparison and linkage of common tropes of the enslavement narrative with a theoretical reading of trauma to illuminate slavery's impact on Black subjectivity as both an individual and communal phenomenon. Douglass' Narrative and subsequent works spare no ink to elucidate the horrors he witnessed and endured; rhetorically, he could not have made a compelling case against slavery or justified his 'rebellion' and flight without doing so. Morrison, likewise, cannot present an accurate portrait of her postEmancipation characters without providing the horrific context of their experiences in bondage. Understanding the characters requires an understanding of what they endured: atrocities individual and collective, and the trauma that proceeds from them.

To begin by naming the cause-and-effect relationship between atrocity and trauma, psychologist Judith Herman offers up a workable series of definitions:

"Psychological trauma is an affliction of the powerless. At the moment of trauma, the victim is rendered helpless by overwhelming force. When the force is of nature, we speak of disasters. When the force of that is other human beings, we speak of atrocities. Traumatic events overwhelm the ordinary systems of 
care that give people a sense of control, connection and meaning" (Herman 33).

Working backward from this definition, the transatlantic slave trade is trauma writ large. An atrocity that spanned 400 years and touched millions of lives, the specter of slavery remains an aggregate of millions of individual moments and events of horrific abuse, cruelty and dehumanization. Herman further describes the effects of that traumatizing force on the victim and/or witness:

"When neither resistance nor escape is possible, the human system of self-defense becomes overwhelmed and disorganized...Traumatic events produce profound and lasting changes in physiological arousal, emotion, cognition and memory. Moreover, traumatic events can sever these normally integrated functions from each other" (34).

Trauma, then, is not merely an experience of fear, pain or dehumanization; it is the ongoing damage that prolongs the traumatizing event over time.

The dialectic of trauma is complex and to focus on one or two symptoms is hopelessly reductionist. Moreover, an extended examination of the clinical data in this field is beyond the scope of this thesis. While extensive work published in recent decades has (by building on foundational work by Freud, Janet and Karbiner) done much establish the etiology and treatment of psychological trauma, it is important to avoid being deterministic in pursuing this line of inquiry. The human psyche is a subtle and resilient entity, and thereby resistant to de facto categorizations and sweeping generalities. O'Brien argues that the "course of the normal response is predictable only 
in the broadest terms. It is affected in populations and individuals by the nature of the trauma, its duration, its meaning; and by the individual's personality, experience, support, and personal role in society and the family. It may differ in duration, intensity and specific symptom constellation" (46). As a result, the symptomatology of trauma may manifest in any number of ways, and at varying levels of intensity and dysfunction, in different subjects. The many factors at play, as listed by O'Brien, could be expressed by the individual subject in varied forms within slavery's various discourses.

However, it is possible to distill a range of "normal" responses to abnormally noxious stimuli which, if recurring over time or sanctioned culturally by custom or law, can have devastating effects on the human subject's view of themselves, their ability to process and retain information appropriately, and their ability to make conscious choices regarding the most basic things. Herman concurs: "The dialectic of trauma gives rise to complicated, often uncanny, alterations in consciousness, which George Orwell...called 'doublethink' and which metal health professionals, searching for a calm, precise language, call dissociation'” (1). Because the term 'dissociation' has been bandied about casually in both pop psychological circles and critical discourse, it is key to this study to define 'dissociation' as accurately and narrowly as possible, within its appropriate therapeutic context. "As traditionally conceived, the concept of dissociation refers to an alteration in consciousness, identity or behavior" (DSM-III-R, APA, 1987). This alteration is not a random, irrational occurrence. "As a cognitive mechanism, dissociation is an alternative way to cope with extreme emotional distress by altering the nature of perception, appraisal, attribution and the schema for enactment" (Wilson 14). 
For the purposes of this study, 'dissociation' is the alteration of objective reality in response to extreme emotional distress.

In other words, the traumatized identity can be subject to a variety of mental shifts that are inherently adaptive and protective, but also place the traumatized subject outside 'normative' definitions of behavior and thought. "The cognitive responses that occur in the immediate and long term aftermath of a trauma refer to...ways of understanding the event that has occurred" (Wilson 13). The shock and anger of the initial assault is compounded by recurring bouts of rage, despair and impotence that are potential sites of re-injury. "Once the ego was traumatized...other stimuli could function so as to become equivalent to the original stressor" (Wilson 4). Certainly Sethe could attest to the devastating, almost malicious power of her own 'rememory,' signaled by a painful return to the sites of her numerous violations and bereavements. Dissociation acts to cushion the recurring psychic blow of unresolved trauma, in which mediating strategies such as "denial, distortion, dissociation, or intrusion... attempt to reduce distress by reducing or augmenting information through safety-oriented responses to threat and vulnerability" (Wilson 17). The dissociated subject responds automatically and unconsciously to new events and information so as to protect itself from what it has already experienced. At times it is as if an alternate personality arises that can cope with situations that the traumatized psyche cannot.

It is relevant to recall W.E.B. Du Bois' concept of double consciousness here, in light of dissociation as a coping mechanism for extreme stress. In his masterpiece, The Souls of Black Folk, Du Bois eloquently explicates the process of discovering his black identity as traumatic and alienating, accompanied as it was by the parallel revelation of 
that black identity being somehow unworthy or tainted: "Then it dawned upon me with a certain suddenness that I was different from the others; or like, mayhap, in heart and life and longing, but shut out from their world by a vast veil. I had thereafter no desire to tear down that veil...I held all beyond it in common contempt, and lived above it in a region of blue sky and great wandering shadows" (Du Bois 8). That deliberate placement of racist perceptions "beyond the Veil," along with the pain and rejection of confronting those attitudes-that is to say, outside of his immediate awareness--is an action consistent with dissociative mental states. The devaluation of Du Bois' self by (white) others, incompatible with his own very strong sense of self, engenders a psychic conflict he claims is at the heart of the African American identity: the alienation that accompanies being considered a "problem" and not a citizen or brother. This constant confrontation of one's second class status is traumatizing to the subject, and Du Boisian doubleconsciousness is one iteration of a self-protective dissociative psychological state in response to that constant and noxious stimuli.

$\mathrm{Du}$ Bois further interrogates the adaptive benefits of this dissonance by repeating its biting irony throughout the text. His assessment of African-American alienation and suppression as engendering the valuable 'gift' of dual consciousness--of being at once American and not, of being part of the American mythological corpus yet denied access to its dearest rewards and privileges--is mirrored in the very real distance between nineteenth century racist discourses and an African-American subjectivity that had to liberate itself from the oppression of that model:

“...The Negro is a sort of seventh son, born with a veil and gifted with second-sight in this American world-a world which yields 
him no true self-consciousness, but only lets him see himself through the revelation of the other (white) world. It is a peculiar sensation, this double consciousness, this sense of always looking at one's self through the eyes of others, of measuring one's soul by the tape of a world that looks on in amused contempt and pity. One ever feels his two-ness-an American, a Negro; two souls, two thoughts, two unreconciled strivings; two warring ideals in one dark body, whose dogged strength alone keeps it from being torn asunder" (Du Bois 9).

Arnold Rampersad, in his introduction to The Souls of Black Folk, comments upon the persistent trope of double consciousness throughout Du Bois' work. According to Rampersad, "the 'souls' of the title is a play on words, referring to the twoness of the black American..." (xv). This duality is echoed by Stamp Paid, a family friend who escorted Sethe across the river during her flight from Sweet Home. When he ruminates on the burdens the black citizen has to endure he gets a clue as to the provenance of the ghostly voices heard around 124 :

“...he believed the undecipherable language clamoring around the house was the mumbling of the black and angry dead. Very few died in bed, like Baby Suggs, and none that he knew of, including Baby, had lived a livable life. Even the educated colored: the longschool people, the doctors, the teachers, the paper-writers and business men had a hard row to hoe. In addition to having to use 
their heads to get ahead, they had the weight of the whole race

sitting there. You needed two heads for that" (198).

The repetition of the word 'head' here is significant. Its use as a symbol for both intelligence ("use their heads") and agency ("get ahead") underscores this dual consciousness's impact on black subjectivity as both alienating and empowering. That it is the site of racial obligation ("the weight of the whole race sitting there") is salient in light of West African spiritual belief, wherein a person's head was the physical location of both their individual soul and the collective spirits of their ancestors. To have two heads, in Hoodoo parlance, was to see oneself as part of an unbroken chain of embodiment, connected back through time to an African genesis. It was to recognize oneself as something other than an excluded and denigrated entity, to embrace the very part of oneself and one's heritage that was devalued and proscribed, and to call upon the aid of forces that were ancient, numinous and mysterious against a sea of New World troubles. Ironically, this affirmation of one's "African-ness" would also bring a deeper and more painful awareness of racism's insidious effects. The doubled consciousness brought the pain of greater awareness of what was denied to the Black subject, at the same time it opened up potential arenas of agency and expression.

The tension inherent in this doubled consciousness is chief among primary tropes common to both the discursive arenas of trauma theory and the enslavement narrative. In both these discourses "the fundamental stages of recovery are establishing safety, reconstructing the trauma story, and restoring the connection between survivors and their community" (Herman 3). In context of both trauma theory and the enslavement narrative, the salient tropes of Beloved--subjectivity, memory, and healing as individual 
and communal processes--are revealed as sites of transformation and resistance. Also, a psychological reading of trauma re-privileges the personal narrative which is at times devalued and/or rendered mute in historical discourses, and supports African-American literary production as a powerful modus of agency in times of severe repression, in part because of its provenance in autobiography. In both these discourses, a paramount part of the victim's 'reclamation' of subjectivity is being able to "speak truth to power," in the form of their personal narratives.

In making the discursive leap linking trauma theory and the enslavement narrative as tropically similar, the critic quickly discovers the risk of pathologizing both the subject and entire genre simultaneously. While artistic expression as both refuge from and resistance to imperialist violence is an ubiquitous phenomenon-one could almost posit that cultural imperialism sometimes inadvertently energizes and promulgates the very indigenous cultures it attempts to deracinate-the recognition of this similarity should not be employed to further ghettoize the narrator, and by extension the entire enslaved population, as somehow inherently pathological. Rather, these negotiations and accommodations can be read as astute adaptations on the part of the traumatized subjectivity to a very hostile environment. Remember, the cognitive shifts that the traumatized subjectivity is susceptible to are normative responses to abnormally harsh conditions. While technically falling neatly under the category of schizophrenia, there is much support for this mental sleight of hand as potentially beneficial.

For example, by further locating this discursive juncture in African American letters, black literary historian Bernard W. Bell asserts, “...the historical pattern of contradictions between ideals of white America and the reality of black America has 
resulted in what I prefer to call...a complex double-consciousness, socialized ambivalence and double vision which are a healthful rather than pathological adjustment by black people to the rigors of the New World" (Bell 5-6, italics mine). He further locates the twin aims of this discourse as therapeutic and artistic by quoting Ostendorf on this dual consciousness as "provid(ing) cognitive and emotive alternatives to an oppressive social arena, both therapy for incipient pathology and emancipation of the senses" (Bell 12). He cites a large body of multidisciplinary research to support this assertion: "Recent research in anthropology, sociology, history, folklore, musicology and linguistics...convincingly supports the belief long held by many Afro-Americans that the conflicts between black culture and white society have resulted in creative as well as destructive tensions in black people and their communities" (Bell 9). This is not to downplay the very real effects of trauma upon the survivor. This is to acknowledge that even under the most oppressive conditions, individuals and communities will find and foster an identity that is creative, resilient and ultimately transcendent over its bondage. One manifestation of that sustaining creativity is the narrative of enslavement.

When Frederick Douglass says in Narrative of the Life of Frederick Douglass, An American Slave, Written by Himself: "You have seen how a man was made a slave; you shall see how a slave was made a man" (47), he proceeds to outline a cognitive process by which he was able to throw off the constrictions of his servitude, both physically and mentally, a process which comes to its fruition in writing his own memoir. According to McFeely, in his writing "Douglass outran being a runaway" (133). Three years after his escape from slavery in Maryland, he gave his first speech in support of abolition. Douglass locates a significant moment in throwing off slavery's internalized 
objectification in agreeing to speak at an anti-slavery conference on Nantucket Island, on August 11, 1841: "(Speaking publicly) was a severe cross and I took it up reluctantly. The truth was I felt myself a slave, and the idea of speaking to white people weighed me down" (Douglass 75). Here, Douglass reveals that, even years after leaving slavery behind him, he is still oppressed by his own internalized 'otherness.' As a consequence, his liberty is at best incomplete, since he is intimidated by his white audiences, and feels that he is not equal to them.

In the years that followed, he became a noted and polished speaker on the Abolitionist lecture circuit, educating himself and refining his rhetorical skills. "The Narrative signaled Douglass' emergence as a committed abolitionist and suggests his developing intellectual skills in those early years of freedom" (Douglass 135). His writings and lectures served many functions: as polemic tools in an ideological battle, as livelihood, as personal expression. But the production of these texts is most significant because they represent Douglass's creation of his own free subjectivity. This narrative and personal trajectory is replicated among the authors of many of the antebellum narratives. In this manner, "...the most memorable antebellum slave narratives treat their arrival on the abolitionist lecture circuit or their acceptance of the anti-slavery pen as the fulfillment of their destiny" (MacDowell and Rampersad 65). The opportunity and will to speak of one's experiences, and the validation proceeding from a receptive and sympathetic audience, is the transformative moment where the reclaimed subjectivity is embodied and self-defined. The formerly enslaved ego itself has transmitted itself, via the self-reflective medium of the personal narrative, into history, into logos, into textual existence. 
The twin aims of this revelatory rhetorical project (therapeutic and selfexpressive), coupled with its overtly moral agenda, gave rise to the next set of problematizing challenges. By engaging in such a blatantly polemic discourse, issues of veracity and credibility importune the formerly enslaved subject. "Whatever else it is, autobiography stems more often than not from a need to explain and justify the self...(in the antebellum period) most Afro-American autobiography addressed itself, directly or indirectly, to the proof of two propositions: (1) that the slave was...' a man and a brother' to whites, especially to the white reader of the slave narratives; and (2) that the black narrator was, despite all prejudice and propaganda, a truth-teller, a reliable transcriber of the experience and character of black folk" (Andrews 1). In short, establishing the narrator's humanity and veracity, in that order, was the foundation upon which the rhetorical 'success' of the narrative rested. These were particular concerns of Black authors, white authors assuming a peership with the (white) reader that a Black author could not take for granted. Christopher Mulvey enumerates these issues in his essay "Freeing the voice, Creating the Self: the novel and slavery": "Questions raised by the conflict between narrative and novel, between support and subversion of slavery, between collaboration and appropriation, entangle African American texts...Issues of authenticity have been central to the critical debate from the beginning" (Graham 20). Concerns over the intellectual provenance of these narratives-are they the genuine productions of African American authors, or of white ghostwriters constructing fictions for propaganda? Are these narratives accurate or are they somehow "corrupted" by the influence of white editors? These issues continue to exert discursive influence in contemporary criticism. 
Aggravating the racial consciousness which added distance and doubt, is a more general desire to render unpleasant truths invisible. "The conflict between the will to deny horrible events and the will to proclaim them aloud is the central dialectic of psychological trauma" (Herman 1). In the space between white ideology and black realities, charges of distortion, exaggeration and plain deceit were leveled at these narratives to attack both their immediate creators and the abolitionist cause which they served.

Frederick Douglass was able to invert an accusation of lying into a verification of both his text and moral premise as valid. After the publication of the Narrative, a white neighbor of Douglass' former owner, Covey, published a critique of it, declaring that the "Fred Bailey" he remembered in Maryland could never have penned such a memoir, and that Douglass was in fact lying about his authorship of the Narrative and the facts contained therein. Douglass concedes that "Fred Bailey" could not, indeed, have written the Narrative, and uses the accusation to both validate his authorship and denounce the dehumanizing effects of servitude:

“..when you knew me I was an unlearned and rather ordinary

Negro... You must not judge me now by what I was then.

Frederick Douglass, the free man, is a very different person that

Frederick Bailey, the salve. I feel myself almost a new man-

freedom has given me new life "(Douglass 93-94).

Part of the freedom that wrought this transformation was the freedom finally to tell his own story, to define his own subjectivity. As Andrews confirms, "ultimately this objectifying power of slavery is what the antebellum slave narrative protests against most 
eloquently by demonstrating the evolution of a liberating subjectivity in the slave life, up to and including the act of writing the autobiography itself" ( MacDowell and Rampersad 64-65). In the act of writing and speaking his narrative, Douglass was both performing himself and forming himself. "Through the power of his narrative, Douglass calls himself from nonexistence into existence the 'onlie begetter' of his own manhood...'Written by himself' certifies that Douglass has authored his own existence in much the same way that naming his own post slavery name as the last words of the text certifies his identity against any and all who might threaten it" (MacDowell and Rampersad 5-6). To author this text was to authorize himself (his self), and closing the text with his chosen name seals this literary act of self-definition.

Douglass' reclamation of his own subjectivity is a discursive and psychological victory that seems mitigated because the content of enslavement narratives had to be verified by a credible white witness, whose role in the production of the printed narrative might vary. A verifying preface by a known, credible, white witness, or the signatures of many, as in the case of Harriet Jacobs' Incidents in the Life of a Slave Girl, was commonly placed to certify and privilege the tale and its teller to the white, middle class audience to whom it was addressed. Perhaps one reason for this anxiety over credibility is that these narratives arise out of the narrator's memory, a notoriously unreliable mental faculty. This re-remembering was not an easy task; no less difficult is the reporting of these facts. Recall Herman's assertion that the will to speak the unspeakable is as strong as the will to deny it, but the victim is requesting, in speaking the tale, that the bystander share the burden of pain. 
That burden of pain is described by psychiatrist Leo Eitinger in Trauma and

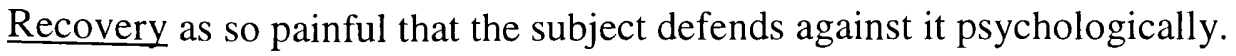

"A veil of oblivion is drawn over everything painful and unpleasant. We

find the two sides face to face; on the one side the victims who perhaps

wish to forget but cannot, and on the other all those with strong, often

unconscious motives who very intensely wish to forget and succeed in

doing so...The weakest one...remains the losing party in this silent and

unequal dialogue" (Herman 8).

In light of hegemonic discourses which either justified or minimized the manifold cruelties of slavery-in short, which mitigated any guilt or deferred any compassion the white population may feel-the enslavement narrative engaged in a "unequal dialogue" within American public life by calling upon the reader to share the horrific burden of slavery, and thereby challenged the reader to admit complicity with or act against it. This moral challenge was inherently loaded, touching upon the most cherished core values of a putatively Christian populace. That the moral question of slavery was entangled by issues of economics, religion and prejudice, made the uncomfortable revelations contained in the enslavement narrative even more provocative to the white reader, and therefore more subject to denial and condemnation.

Moreover, to tell the tale carried a great deal of risk, for uncertain rewards. One risk was the pain and re-traumatizing effects of reliving horrific memories while speaking or writing the narrative. "Reconstructing their past lives required many ex-slaves to undergo a disquieting psychic immersion into their former lives as slaves" (Andrews 7). This anxiety informs the narratives' stylistic and rhetorical approaches. For Douglass and 
Jacobs, that anxiety is manifest in the parts of their narratives they felt they needed to suppress, for reasons already mentioned. In Beloved, the personal narratives of various characters unfold in a way consistent with the truth-telling of traumatized individuals in the process of recovery. "People who have survived atrocities often tell their stories in a highly emotional, contradictory and fragmented manner which undermines their credibility and thereby serves the twin imperatives of truth-telling and secrecy" (Herman 1). Sethe begins healing the wounds of slavery even before she arrives at Baby Sugg's, by telling her story to Ella: "Ella wrapped a cloth strip tight around the baby's navel as she listened for the holes-the things the fugitives did not say, the questions they did not ask. Listened too for the unnamed, unmentioned people left behind" (Morrison 92). "Listening for the holes" is an apt description of the inconsistencies in many enslaved narratives. For these "holes" do not represent an absence, but rather the presence of things that cannot be spoken. The personal narrative, the narrative of slavery and escape, occurs in the interplay between what is stated and what is inferred, and what is suppressed entirely. But Morrison deliberately constructs the narrative as the definitive statement of the liberated subjectivity and as the first step in healing from slavery's traumas.

In Beloved, the personal narrative-when it is told, and how, and to whom-is central to the novel's plot. And as it has been shown, the act of speaking the tale carries great risk. When Paul D. finally hears Sethe's story it leads to more fragmentation and alienation, via yet another displacement away from a stable family. His commitment to making a life with her is best summed up when Morrison writes, "He wanted to put his story next to hers" (299). He longs to form the connection with Sethe that he had never 
been able to have, had never been allowed to have, and locates the mutual healing in resolving their pasts as putting their stories together. But unable to bear the pain of her narrative, he questions her resignation to her fate, exemplified by her refusal to leave the haunted house at 124 Bluestone Road. This questioning, couched in a statement so dehumanizing to Sethe that they literally cannot move forward together, leads to Paul D. leave the house, thereby abandoning her to Beloved's subsequent reign of terror. This dis-integration of their newly formed household is (perhaps) remedied by the novel's end, but it is emblematic of the larger, direr disunity between Sethe and the black community in Cincinnati which betrayed her and her children, and caused "the Misery."

The anxiety of disclosure accounts for the rhetorical maneuvers and evasions of the traditional enslavement narrative. These maneuvers and evasions are also manifest in the circuitous fashion by which Sethe attempts to relate the story of her daughter's death to Paul D. Having previously mentioned Beloved's death, her own abortive recapture and subsequent jail time almost in an offhand manner, Sethe's explanation of why she killed one child in attempting to kill all four comes out almost torturously, for both her and Paul D. As Page relevantly states, that "shocking act, Sethe's motivations behind it, the memory of it, and Paul D's struggle to understand it, form the heart of the novel. As she attempts to tell him about the murder, she nervously circles around the kitchen, around Paul D...Gradually she does close the circle enough to tell Paul D the truth" (Page 135). The chapter containing Sethe's explanation of the murder-already revealed in third person through Baby Suggs' perspective-begins in the center ("she was already crawling when I got here" [159]) and spins outward. Paul watches as Sethe 'spins' her tale: 
"She was spinning. Round and round the room...Paul D sat at the table watching her drift into view then disappear behind his back, turning like a slow but steady wheel... Once in a while she rubbed her hips as she turned but the wheel never stopped" (159).

It is a rhetorical strategy that Sethe knows is inadequate to the task of accurately explaining why she killed her child:

"Sethe knew that the circle she was making around the room, him, the subject, would remain one. That she could never close in, pin it down for anybody who had to ask. If they didn't get it right off-she could never explain" (163).

For Sethe, re-engaging the past through her memories and her life story yields dubious rewards while demanding much emotional risk and effort. As Sethe says, it's hard work, beating back the past.

For Denver, born during Sethe's flight from Kentucky, her mother's narratives about her life in slavery occupy the same ambivalent position as traditional enslavement narratives as discussed earlier: they are both highly privileged and highly suspect. "Denver hated the stories her mother told that did not concern herself, which is why Amy was all she ever asked about" (62). Completely isolated in 124 with no friends or outside contacts besides her mother and the ghost, missing her brothers and grandmother, Sethe's tale of her birth secures for Denver a variety of contexts that can claim her. Her birth during Sethe's flight marks her for distinction: she is the only black character in the book that has not lived under slavery. While that locates her as a culmination of her enslaved parents' dreams and wishes, it also sets her at a distance from the previous, formerly 
enslaved generation. Her distaste for reliving those days through reminiscing is palpable when she sarcastically says: "How come everybody run off from Sweet Home can't stop talking about it? Look like if it was so sweet you would have stayed "(13).

Her animosity to Paul D begins in astonishment at her mother's intimacy with him, then moves to jealousy over the memories they share that she does not: "Someone her mother wanted to talk to and would even consider talking to while barefoot...Hot, shy, now Denver was lonely" (12). She feels further exclusion because this strange 'hazelnut' man knew her daddy ("knew him well") better than she did, putting her on the outside again. Denver aligns with Beloved's corporeal presence to combat the usurping presence of Paul D., only to end up excluded by Beloved and Sethe once Paul D. is gone. Denver's isolation in 124 has deprived her of, among other things, her own life and therefore her own life story. Her need to be anchored in life via her mother's story is made more poignant in that there is no other story for Denver to occupy, while she is a prisoner of 124 and the past. Her resentment at not being part of these epic narratives that have determined the tenor of her days is not alleviated until she is compelled to leave 124 and seek help. At this perilous moment, with Beloved's reign of terror beginning to threaten the life of her mother, Denver must break the silence she has been held in, and ask for help by telling her story. It is emblematic of the recuperative necessity of telling the story that Sethe's silence, condemned as pride by the rest of the community, locks her and her daughters in spiteful 124 , and puts her life in danger. As the three women begin slowly to starve, Denver encounters the dangers of silence: "Denver, who thought she knew all about silence, was surprised to learn that hunger could do that: quiet you down and wear you out" (239). As much as Beloved is fed by Sethe's stories, Denver is 
literally starving from the lack of her own narrative. It is only when she reluctantly opens up her tale about what's happening in 124, that gifts of food begin appearing in the yard. Consistent with the tropes of the enslavement narrative, the recuperative power of Denver's narrative is delayed through her own ambivalence regarding the risk of telling the truth and the risk of remaining concealed in silence, her fears of not being believed or helped: "It was a little thing to pay, but it seemed big to Denver. Nobody was going to help her unless she told it---told all of it" (253). And it is true: it is only via the medium of Denver breaking silence, that the community of women can intervene, intruding into the protective bubble of 124 's isolation to drive off the angry spirit and prevent Sethe from murdering Mr. Bodwin.

For Beloved, her mother's narrative is nothing less than life itself. As much as Sethe may wish to beat back the past, atrocities cannot remain buried. Despite her reluctance to engage her past directly, Sethe must confront the ghost of her murdered child. Indeed, with the appearance of Beloved, in the form of a mysterious, ailing woman who simply materializes in their yard one afternoon, all the inhabitants of 124 are forced to engage with the past. Materializing only after Paul D. banishes the "haint" from 124, Beloved is embodied at the age she would have been, had she not died when she was just a crawling-already? baby. Beloved in the narrative has a variety of functions. She is the ghost of Sethe's murdered child, but she is also an emanation of any or all the millions of people who perished in Middle Passage or on arrival in a hostile New World. As such, Beloved's individual tale, the one that must be told in order to lay her to rest, is the tale of all those millions. 
Certainly, the primacy of the personal narrative seems further privileged as Beloved 'hungrily' devours Sethe's stories. As a two-year-old, her own memories are not fully formed ["how can I say things that are pictures" (210)], so in soliciting Sethe's memories, Sethe tells Beloved's story as well as begins to engage her own, feared memories. It is here that the personal narrative comes into prominence. Beloved, unlike the traditional slave narrative, is not one story told by first-person narration. Rather, it weaves together a variety of narratives, using Sethe's narrative as the "woof." The telling, and how, and to whom, is revealed more slowly than is perhaps typical of traditional enslavement narratives. However the power of each telling, and the consequences of those verbal iterations of memory, provides sites of greatest tension and change. For Sethe finally telling her story, first to Paul D and then to Beloved, invites danger, violence and trauma, but also opens the door to healing and resolution for herself, the child who died, the child who lived and the community as a whole. The past that she's been holding at bay begins to be healed in relating this narrative:

"It became a way to feed her... Sethe learned the profound satisfaction Beloved got from storytelling. It amazed Sethe (as much as it pleased Beloved) because every mention of her past life hurt. She and Baby Suggs had agreed without saying so that it was unspeakable...But as she began speaking about the earrings, she found herself wanting to, liking to" (58). Sethe's initial reluctance to engage her past eases as Beloved elicits the stories from her. From here, the pain of remembrance manifests its full horror, and puts Sethe in mortal peril. Moving into this peril, and her ultimate deliverance from it, are precisely what lays Beloved to rest, heals the family, and reconciles them back into their community. 


\section{CHAPTER THREE: THE PERSISTENCE OF MEMORY}

Waiting for the ease, the space that need not be filled with anything other than the drift of their own thoughts. But they wouldn't like it. They are busy and thinking of ways to be busier because such a space of nothing passing to do would knock them down. No fields of cowslips would rush into that opening, not mornings free of flies and heat when the light is shy. No. Not them. They fill their minds and hands with soap and repair and dicey confrontations because what is waiting for them, in a suddenly idle moment, is the seep of rage. Molten. Thick and slow-moving. Mindful and particular about what in its path it chooses to bury.

Toni Morrison, $\underline{\text { Jazz }}$

Having interrogated the personal narrative in context of both trauma theory and African-American autobiography, utilizing Frederick Douglass's Narrative of an American Slave to rehearse common tropes of the construction of Black subjectivity as filtered through issues of veracity, authority, concealment and revelation, I now turn to my core project of elucidating these tropes as they manifest in Beloved. Since Beloved is essentially a redemptive and recuperative text, I find Judith Herman's rubric of trauma recovery to track the narrative arc that Beloved traces. In this model, one finds the healing process broken down into three stages: the re-establishment of safety; remembrance and mourning of the traumatic event(s); and finally reconnection to daily life via strengthened ties to community and family. This progression follows the narrative arc of the novel almost literally. Divided into three sections, each opening with a brief statement of 124's emotional state, the action of Beloved is Sethe's journey through these three stages towards her own healing.

The first step in trauma recovery is to re-establish safety, and in a sense, the entire novel is about the exertions of the main characters to do so. The need to be 
safe is what precipitates the flight from Sweet Home. Despite having been enslaved for much of their lives on Sweet Home, it is only during Schoolteacher's tenure that conditions become violent enough for the Sweet Home men and Sethe to contemplate running away. But a quick glance proves that safety is a relative term in context of 124 Bluestone Road, Cincinnati, Ohio. When Beloved opens, Sethe, eighteen years out of Kentucky, has apparently established a safe haven for herself and Denver. They have a home, and Sethe is employed and able to provide for them both. But Morrison won't allow that safety to remain unexamined. First, she makes reference to the racist violence to which the Black community is still vulnerable: "Desperately thirsty for black blood, without which it could not live, the dragon (the Klan) swam the Ohio at will" (Morrison 66). Stamp Paid concurs with Baby Suggs, when he finds a red ribbon tied on a lock of kinky black hair, that even after slavery, "there ain't no bad luck in the world but white folks." To be Black is to have atrocities visited upon you at any moment, for any reason or none at all, atrocities which are so ubiquitous that they can be described in graphic detail or merely mentioned by casual allusion. It is necessary to take this racist violence "as written," as it were. This violence is emblematic of the challenges which faced Black America during the time of Reconstruction, and its presence here is consistent with contemporary "neo-slave" narratives which critique traditional notions of Northern "freedom." While individual or collective incidents of racist violence can be deconstructed along any number of theoretical lines, there is no mitigating or justifying the fact that this violence is culturally sanctioned and 
supported. This violence, the mere threat of it, forms the background of this novel, even when it does not manifest in full bloom and crowd out everything else.

In addition to the racist violence to which Black people are still subject despite Emancipation, Sethe and Denver's safety is only relative given that they live in a haunted house, and the "rebuked and lonely" spirit that plagues it is "spiteful (and) full of a baby's venom" (1). While the ghost's antics are usually inconvenient as opposed to violent, they do serve to perpetuate one of the more devastating aspects of enslaved life: disrupted families. Baby Suggs' and Sethe's tolerance of this uncanny presence infuriates Sethe's sons, who leave "the moment the house committed what was for him the one insult not to be borne or witnessed a second time" (1). Their departure deepens Denver's isolation and loneliness, most poignantly located in her absolute removal from the black community. This isolation eventually allows for Beloved's reign of terror, which nearly costs Sethe her life. So this 'safety' that Sethe has constructed in Cincinnati is material and physical, but also comes at the very high price of further displacement, isolation, and finally, more violence. It was certainly purchased dearly enough, as Sethe insists to Paul D when she explains why she will not move: "I will never run from another thing on this earth. I took one journey and I paid for the ticket, but let me tell you something, Paul D Garner: it cost too much!" (15). Having paid for her meager comfort with the blood of "her best thing," she will not move herself away from the punishment and reproach of the angry ghost. Besides, running from that house would only lead them to another house "packed to its rafters with some dead 
Negro's grief" (5). In Beloved, all of Paul D's wandering notwithstanding, there is no point in running from the past; it never truly leaves you.

Perhaps the issue of safety is never more problematic than during Sethe's revelation of 'the Misery' to Paul D:

'"I stopped him,' she said, staring at the place where the fence used to be. 'I took and put my babies where they'd be safe.'

The roaring in Paul D's head did not prevent him from hearing the pat she gave to the last word, and it occurred to him what she wanted for her children was exactly what was missing in 124 : safety....He thought he had made it safe...but what she meant could cleave the bone. This here Sethe talked about safety with a handsaw" (164).

It is here that the risk in telling the tale, discussed in the previous chapter, is most evident. From the burgeoning 'safety' of their fragile alliance, alienation, disruption, and further displacement immediately follow Sethe's revelation to Paul D. It is from this point that a forest of misunderstanding, "trackless and quiet," springs up between them. Unable to accept Sethe's crime as her only option, Paul D leaves; Sethe is hurt by his horrified rejection, and their delicate alliance is shattered until the novel's end, by which point Sethe's precarious safety is completely replaced by life-threatening peril. Thus, the safety that Sethe has won for herself and her sole child also acts as a potential site of further injury. In this manner the events of the past inform and impact the choices and actions of the present. Moreover, Sethe's conception of 'safety' establishes the fact that there is 
also a terrible risk in acknowledging the past, as when Paul D's rejection continues to imprison Sethe long after she is released from jail.

For this reason, physical safety notwithstanding, the threat that Sethe fears most is the past. Having experienced all that she has, Sethe can only be frightened by her own memories of the past, and the only threats to her and the life she has built arise after she reveals these memories. This fear-of one's memories, of the risks in revealing one's memories--is absolutely consistent with the dialectic of trauma, where it is known that atrocious, or "intrusive," memories can re-injure the subject. Herman explains:

"Long after the danger is past, traumatized people relive the event as though it were continually recurring in the present...The traumatic moment becomes encoded in an abnormal form of memory, which breaks spontaneously into consciousness... as flashbacks during waking states...”(Herman 37).

One finds this phenomenon poignantly at work in Sethe's psyche, as a random sight or sound sends her back in time and space to her own enslavement:

“... and suddenly there was Sweet Home rolling, rolling, rolling our before her eyes, and although there was not a leaf on that farm that did not make her want to scream, it rolled itself out in shameless beauty. It never looked as terrible as it was and it made her wonder if Hell was a pretty place too... Boys hanging from the most beautiful sycamores in the world. It shamed her-remembering the wonderful soughing trees rather than the boys. Try as she might to make it 
otherwise, the sycamores beat out the children every time and she could not forgive her memory for that" (6).

For Sethe, memory becomes an arena for the atrocities of the past to continue injuring her, long after she escapes from slavery.

These memories are not always volitional, and their intrusion into her thoughtsinto her subjectivity -is a source of shame: "try as she might to make it otherwise...she could not forgive her memory for that." Part of the ongoing trauma that can never seem to heal, is that memory, or 're-memory' as Sethe calls it, has the power to re-injure by bringing up feelings of pain, loss and impotence that cannot be comforted:

"She shook her head from side to side, resigned to her rebellious brain. Why was there nothing it refused? No misery, no regret, no hateful picture to rotten to accept? Like a greedy child it snatched up everything. Just once, could it say no thank you? I don't want to know or have to remember that" (70).

Therefore, for Sethe, selective amnesia becomes an adaptive strategy: "she worked hard to remember as little as was safe" (6), because she is engaged "in the hard work of beating back the past" (72). As Sethe tells Paul, the night before the carnival, "I don't go inside" (46). Sethe's reluctance to engage her memories makes it impossible for the cycles of healing to complete, and threatens the putative 'safety' she has manifested. The second step of remembrance and mourning will bring Sethe closer to healing, but her reluctance to do this puts her hard-won safety in jeopardy.

As noted previously, by engaging the process of telling the story of trauma the teller incurs a variety of risks, not least of which is the arduous and painful task of re- 
engaging the past via memories of horrific abuse. Despite the pain involved, re-engaging those memories and telling the story is indispensable to remembrance and mourning, and therefore healing. In finally telling the story of Beloved's murder to Paul D, Sethe is taking a necessary step towards her own healing, by examining the memories she had worked so hard to keep at bay. However, reconstructing the memory for Paul D-trying to accurately explain why she did what she did-also makes her subject to further rejection, misunderstanding and pain. His departure initiates a series of events which make healing possible, but only through a violently physical confrontation of and immersion in the past.

Paul's departure represents an opportunity for healing about which Sethe feels, at best, ambivalent. After 'feeding' Beloved's physical self with her life story, Sethe attempts to justify her actions and gain forgiveness that, in the end, she doesn't really want:

"(Denver) had begun to notice that even when Beloved was quiet, dreamy, minding her own business, Sethe got her going again. Whispering, muttering some justification, some clarifying bit of information to Beloved to explain what it had been like, and why, and how come. It was as though Sethe didn't really want forgiveness given; she wanted it refused. And Beloved helped her out" (252).

Sethe's desire to be liberated from the punishment of her own memories is in conflict with her belief that she cannot, and indeed should not, ever be released from this penance. This leads her to make a nearly fatal mistake. She wants to believe that Beloved's return means that she is liberated from the burden of her memories, when in fact Beloved's return signals the embodiment of all the anguish and pain that Sethe has been assiduously repressing for eighteen years. In context of trauma recovery, engagement with memories is so painful 
that the subject will avoid those memories at all costs. Sethe wants to believe that Beloved's re-appearance negates the murder and the subsequent ostracism, that Beloved's return is a corrective to Sethe's atrocious act, and that by rendering the murder a moot point, Sethe is in effect liberated (acquitted might be more accurate) from her burden of memories.

The day after Sethe admits to herself that Beloved is in fact her daughter, she surrenders herself to the fantasy that she is forgiven, that her daughter understands, that she is done paying for this crime. In short, that she no longer has to endure the penance of remembering. Contained within the second part of the novel (the remembrance and mourning portion), Sethe's shift in perception is signaled by the seamless shift from third person narration detailing her daily activities while in public, to a first person, interior monolog as she walks home from work alone:

"Trudging in the ruts left earlier by wheels, Sethe was excited to giddiness by the things she no longer had to remember.

I don't have to remember nothing. I don't even have to explain. She understands it all" (183).

The supreme irony here is that, in the day-long rumination on what she no longer has to remember, she is replaying these memories at length:

"Wrapped tight, hunched forwards, as she started home her mind was busy with the things she could forget.

Thank God I don't have to rememory or say a thing because you know it. All. You know I never would have left you... When the train came I had to be ready" (191). 
The shift from the self-congratulatory tone to the memory of her last, most horrifying day at Sweet Home occurs within a few seconds. The past is not beaten back at all, but overwhelmingly omnipresent, crowding out the moment with memories till Sethe can reach the timeless bliss that 124 has become.

While Sethe's contradicting attempts to both win and defer Beloved's forgiveness puts her in further peril, engaging these memories and re-constructing the story for Beloved is absolutely necessary for her own salvation. "This work of reconstruction actually transforms the traumatic memory, so that it can be integrated into the survivor's life story" (Herman 175). This shift is made evident at last, when Sethe declares to Paul D, simply, "She was my best thing." At the end of the horror, after circuitous attempts to simultaneously reveal and conceal her story in order to protect herself from 'the nastiness of life,' Sethe is able to acknowledge and name her loss, let it go and reconnect with the living: Paul D, Denver, and an allusive next generation that is implied in Nelson Prince's tentative courting of Denver in the final chapter. But this can happen only after she has fully engaged with her memories and mourned her lost child.

For Paul D, too, memory brings no comfort; just a string of recollections of violence and violation. Unlike Sethe's dubious safety in remaining anchored to 124, Paul D has found a respite from remembering in constant motion, and remembrance and mourning alike have been postponed until he arrives at 124 Bluestone Road. Finally at physical rest ("took off my shoes, took off my hat"), he immediately has to re-engage with his memories and his losses. The traumatic effects of slavery have resulted in a constriction of his imagination and agency, where he asks of life only what maintains living and keeps memories at bay: "If he could do those things-with a little work and a little sex thrown 
in-he asked for no more, for more required him to dwell on Halle's face and Sixo laughing" (41). Upon their re-union, Sethe and Paul D naturally bring each other up to date on what happened since the flight from Sweet Home, and Sethe begins, circuitously, to tell him about the murder of her daughter. But at a certain point during her first, abortive narration of the story, the tale elicits memories within Paul which are too painful for him to continue listening: "Paul D. turned away. He wanted to know more about it, but jail put him back in Alfred, Georgia" (42). Indeed, his desire to "put his story next to hers" comes after painful moments of comparing their respective memories-notably, finally putting it together that Halle was caught in the barn loft and saw Sethe's assault, and was perhaps so traumatized that he could not join the party heading north. When confronted with the newspaper clipping of Sethe's arrest, Paul D. attempts to deny those facts ("that ain't her mouth") much as he has heretofore attempted to flee his own painful memories in constant motion from place to place. The accumulated weight of his traumatized memory-snippets and symbols of which float through his conscious mind, alluding to each of the horrific narratives he has related-all these have the power to make him feel physically ill and morally paralyzed:

"A shudder ran through Paul D. A bone-cold spasm that made him clutch his knees. He didn't know if it was bad whiskey, nights in the cellar, pig fever, iron bits, smiling roosters, fired feet, laughing dead men, hissing grass, rain, apple blossoms, neck jewelry. Judy in the slaughterhouse, Halle in the butter, ghost-white stairs, choke-cherry trees, cameo pins, aspens, Paul A's face, sausage or the loss of a red, red heart" (235). 
These 'random elements' represent a lifetime of abuse, violence and suppression, and each one is metonymic of Paul D's life story.

Perhaps it is Beloved herself who most embodies the power of memory in the text. For her, memory is identity. As a ghost, her existence by and large depends on the memories of the living to keep her anchored to the physical plane of existence. To undersrand the interdependence between memeory and identity for Beloved, it is necessary to understand the role of the dead in African religious and philosophical discourses. The significance of ancestry is more deeply explicated in a subsequent chapter, but its association here with memory is not to be underestimated. Lynch describes the relationship between the dead and the living thus:

"In many traditions throughout Africa, ancestors are not truly dead in the final sense of the word. Although unseen, they are forces in the lives of the living and can be called on for guidance and protection...Ancestral spirits were usually seen as spiritual guardians who protect the community against enemies" (Lynch10).

In reciprocity for their guidance and assistance, ancestors must be remembered, spoken of and ritually placated with libations of food and drink. Remembering Beloved is a radical departure from this model: memories of her bring pain, not comfort, and she is not an ancestor, but rather a descendant, a child. She is not a sage elder to be consulted, but a scared, willful child to be comforted.

Stylistically, Beloved's centrality to the text is evidenced by the eponymous title. Beloved - not even a living being, but a ghost and a memory, the presence of an absenceoccupies a privileged place in the novel over all the characters, which not even the putative 
protagonist, Sethe, can usurp. In interrogating the significance of memory as represented in Beloved's character, it first becomes necessary to determine who or what, exactly, is Beloved. A logical fiction is latched onto when the mysterious girl arrives at 124 , recalling rumors of a local white man who kept a black girl secretly imprisoned in his house, but none of 124's residents truly believe it. Clues such as her line-free hands, the faint scar of saw teeth under her chin, the mark of Sethe's fingernails on her forehead, her lack of coherent memories, her childishness, all point to the physical Beloved being the embodied ghost of the murdered child, manifesting at the age she would have been, had she not been murdered. Denver and Sethe both know this upon seeing the scar, and hold the secret inside themselves until there is no need to keep it from each other.

Beloved, interrogated as to her identity and origin, is far more forthcoming with Denver about her own sketchy memories, than she is with Sethe or Paul D:

“'Dark,' said Beloved. 'I'm small in that place. I'm like this here.'

She raised her head off the bed, lay down on her side and curled

up...'Hot. Nothing to breathe down there and no room to move in...A

lot of people is down there. Some is dead "'(75).

In Beloved's description of "where she was before here", clues indicate that she is more than the ghost of one murdered child. Her description of a hot, dark, cheerless place with nothing to breathe, inhabited by dead bodies, is consistent with some African conceptions of the afterlife, and with descriptions of the Middle Passage from Africa to the New World in the holds of slave ships. Furthermore, talk of a "bridge" between that place and this, mediated through running water (the creek, the ocean), and a sense of time passing measured through intermittent periods of light and dark; all of these hearken back to 
Africanist discourses of death and the afterlife. Their invocation here further locates Beloved's presence as something uncanny, as an intrusion into the world of the living by the dead. Traditionally an intrusion such as this would have signaled deep disharmony and dis-ease in the haunted family, and it is no different here. Beloved's disruptive intrusion into Sethe's life is analogous to the disruptive intrusions of re-memory that Sethe vainly seeks to avoid, and like those intrusions, signals the possibility of healing through a painful process of re-awakened awareness. It is important to note that the efforts of the larger community traditionally would have been necessary to lay the anguished spirit to rest, but Sethe's alienation from the community seems to preclude this possibility, a point to which I will return in the next chapter, when the Black community's role in Sethe's recovery will be addressed fully.

The intrusion of the dead spirit into the world of the living punches a hole between two realms that are usually appropriately separate. The communication between them, via 124 and Beloved, manifests in the "nest of voices" surrounding 124, of which the inhabitants seem unaware, but which can be heard from the road, as Stamp Paid discovers when he pays his first visit to the house since Baby Sugg's funeral:

"Out on Bluestone Road he thought he heard a conflagration of hasty voices-loud, urgent, all speaking at once so he could not make out what they were talking about or to whom. The speech wasn't nonsensical, exactly, nor was it tongues...All he could make out was the word mine" (172).

These hasty voices locate Beloved as the persistence of a restless spirit at the site of her demise, and also hint at the untold and nameless dead who died in the transatlantic slave 
trade, and whose ghosts cannot be laid to rest. Beloved as such embodies one iteration of these countless stories, and therefore carries all of those stories back with her into the world of the living. That cacophony of disembodied voices is the unintelligible chorus of lost and tortured souls, the burden of unexpressed pain: "Mixed in with the voices surrounding the house, recognizable but undecipherable to Stamp Paid, were the thoughts of the women of 124, unspeakable thoughts, unspoken" (199). The babble is the sum of those untold narratives articulated too late, and then only as gibberish. Thus, the casualties of Middle Passage come to mind in Beloved's description of where she was before: the hot, airless space where she couldn't breathe or move. The countless dead are further invoked by the mysterious voices that clamor around 124 , staking a claim upon the house and the women within it in lieu of a final resting place. In asserting their right to 124 ("mine"), they are refusing to be uprooted again. Like Sethe, they will never run from another thing on earth. They have attached themselves to 124 and will not let go without a fight.

But just as memories cannot take the place of living, neither can Beloved remain permanently embodied. Like her mother's memories, she must be confronted in order to be laid to rest, so that Sethe and Denver can move forward with their lives. Long denied and 'rebuked,' Beloved clings to her second life desperately, but finds herself fading corporeally as Sethe begins looking forward to a life with Paul D:

"Beloved, inserting a thumb in her mouth along with the forefinger, pulled out a back tooth.... and thought, This is it. Next would be her arm, her hand, a toe. Pieces of her would drop maybe one at a time, maybe all at once...It is difficult keeping her head on her neck, her legs attached to her hips when she is by herself. Among the things 
she could not remember was when she first knew that she could wake up any day and find herself in pieces" (133).

For Beloved, Sethe's moving forward would mean the annihilation of the memories through which she remains alive and connected to her mother. No wonder she obsessively pursues Sethe with her eyes, and attempts to anchor herself on the material plane by conceiving a child through Paul D, a child that would correct the disruption of Beloved's death by furthering Sethe's bloodline into a subsequent generation.

. The displacement and disruption of families within the slave milieu had a devastating impact on African kinship structures and discourses of ancestry. Ancestry holds a privileged position in African social and religious life, where the care of the dead and their memories by their descendants acts to transmit memories of the past to the subsequent generations. It is one of the more poignant displacements in Beloved that the natural order of this discourse is disrupted. Rather than Sethe's children remembering her after her death, she remembers her three absent children, but admits their memories are fading. Beloved is the most powerful child of Sethe's memory, and in an attempt to become re-embodied, she attempts to join that chain of generations that slavery so disrupted. The gift Beloved potentially offers Sethe-the perpetuating of her bloodline, with a new baby of Sethe's blood to care for and love-holds a chimerical promise to make up for the loss of her children and to anchor her into the fragile weaving of ancestry.

With the three oldest children completely absent, there is a special importance attached to Sethe's last child, the child who is still present at 124 , the one who has not run off or died, the one child that Sethe has kept with her. Denver, perhaps more than anyone in the novel, embodies the role of memory in the formation of identity. Denver begins as a 
tragic figure because the memories that inform her subjectivity are not her own. Denver's lonely, constricted life-bounded by a yard she will not leave, with only ghosts and other people's memories for company-manifests in her preference for only one story: the story of her birth. That story, which she requests again and again from her mother, shapes and defines her, and locates her as the child of Sethe and the absent Halle, a charmed child 'with her daddy's sweet face' whose very existence is proof of supernatural protection. But the story, by defining her, also severely limits her. Until she finally steps off the porch in order to seek help and work, Denver inhabits her own imagination, peopled only with the memories of her absent loved ones and an awareness of her own isolation: "All that leaving: first her brothers, then her grandmother-serious losses since there were no children willing to circle her in a game or hang by their knees from her porch railing" (12). The story of her birth is physically anchored in the landscape of 124 , and it literally anchors Denver there as well:

"Easily she stepped into the told story that lay before her eyes on the path she followed away from the window... And to get to the part of the story she liked best, she had to start way back: hear the birds in the thick woods, the crunch of leaves underfoot; see her mother making her way into the hills where no houses were likely to be" (29).

To fall mentally into the story of her birth, Denver moves in a sort of walking meditation through the environs of 124, retracing Sethe's steps to the house for the first time, on blasted feet with a newborn (Denver herself) tied to her chest. For Denver, her mother's memories are more vital and alive than her present reality, and she re-enacts the story 
physically by walking through the woods and fields around her home. In this way, Denver lives literally surrounded by Sethe's memories and the story of Denver's birth is physically embedded in land around her. This echoes Sethe's memories of having to bring some twig or leaf into the kitchen at Sweet Home, to make it her own, or else her duties would go awry.

Denver is a fairly passive figure in the beginning of the novel, and seems quite paralyzed and unable to act with agency. However it is she who becomes the primary force in affecting a rescue. Denver's importance in healing Sethe and the community that betrayed her family seems emphasized by her strong presence in the third and final section of the book. In Herman's rubric, the third and final step in healing from trauma is the reconnection to community, and it is Denver who makes this possible by doing something which is incredibly frightening for her. Denver's decision to seek help for her mother is an important step for her psychologically, in that she has finally projected herself forward into life. An eloquent example of Denver's growth and emerging subjectivity is that Denver's own memories are brought forward at the opening of the third section to describe the events at 124 and define the danger to Sethe.

Now convinced that she and Sethe are in mortal peril, Denver exercises agency by taking a first terrifying step off the property of 124 : "So it was she who had to step off the edge of the world and die because if she didn't, they all would" (239). It is April ("The weather was warm; the day beautiful...everything alive was tentative" [243]) when Denver analyzes the slow but steady rise in violence and anger at 124 since January, marking the subtle shifts in affection and intimacy between her mother and Beloved that have ultimately led to full-on scenes of abuse. Having analyzed those recent memories, Denver must now 
also rely on her own memories to guide her to help. Her memories lead her to Lady Bishop's, where she briefly attended school as a child. And she marvels at how well her memory is able to lead her there: "She would have known it anywhere. The post and scrap-lumber fence was gray now, not white, but she would have known it anywhere" (246). By requesting help for her family, the community of Black women is alerted to Sethe's plight, and they come forward with gifts of food to both assist the inhabitants of 124, and also to repay Baby Suggs for her kindness and to make amends for their part in the Misery.

Despite the devastating effects of Beloved's uncanny appearance, Morrison does model an example of an appropriate interaction between the dead and living, which in African belief is based on remembrance and aid. When Sethe or Denver are troubled, they steal away to keeping-room or the emerald closet, respectively, to seek for Baby's presence, which never fails to comfort them. More specifically, when Denver forces herself go for help, Baby's "ghost" accompanies her, guides and exhorts her to be brave:

"Remembering those conversations and her grandmother's last and final words. Denver stood on the porch in the sun and couldn't leave it. Her throat itched, her heart kicked—and then Baby Suggs laughed, clear as anything. 'You mean I never told you anything about Carolina? About your daddy? You don't remember nothing about how come I walk the way I do and about your mother's feet, not to speak of her back? Is that why you can't walk down them steps? My Jesus my.'

You said there was no defense. 


\section{'There ain't.'}

Then what do I do?

'Know it, and go on out the yard. Go on'” (244).

From beyond the grave, at a time of dire peril to what's left of her family, Baby Suggs reaches out to her granddaughter to propel her towards help, by evoking the same Gospel of psychic liberation she once preached in the Clearing. One effect of the precarious "safety" Sethe has won for herself and Denver, is that Denver is paralyzed with fear of white people. Stepping off the porch, moving into the world of white people, means putting herself in mortal danger, and she is unable to make the leap until Baby exhorts her acknowledge her fear but do it anyway. In effect Baby is urging her not to let fear rule her life, as fear has ruled the lives of her mother and grandmother. It is a profound assertion of a liberated subjectivity.

124 is the arena within which Morrison's characters enact dramas of union, dissolution and separation. These dramas are in deadly earnest, and the stakes for all the characters are very high as remembrance and mourning become the medium of exchange in their lives together, even as they run from both of these threats.. It is the act of remembering and giving full mournful voice to one's losses that allows the traumatized psyche to move out of the past and into the present; out of isolation and back into the community; out of invisibility and back into history; out of the bondage of a traumatized and suppressed self and into the wholeness of an emancipated, sovereign subjectivity. 
CHAPTER FOUR: ANCESTRY, DISPLACEMENT AND REDEMPTION: HEALING WITHIN THE COMMUNITY

Finally I come to the last stage of the healing process: the traumatized subjectivity's reconnection to the larger community. The disconnections that are endemic to those touched by slavery are not just manifest in the cognitive breaks and the altered, anguished consciousness that Beloved's characters experience. Slavery in its most essential form is based in disconnection and displacement, and is fueled by dehumanization and violence. Any true understanding of the narrative stakes in Beloved requires an understanding of the characters in the context of slavery. For that, a more thorough examination of the "peculiar institution" is necessary.

As was stated before, the Transatlantic slave trade was trauma writ large; the experiences of Sethe and her family are microcosmic of an elaborate and overweening commercial and imperial endeavor that radically altered and shaped Atlantic culture in the modern period. In elucidating the many discourses contained within the body of the slave trade, the scholar must begin with the initial atrocity, the Original Sin of Empire, as it were. The abduction and sale of African persons into the Transatlantic slave trade displaced millions of people from their families and homes. Once arrived in the New World, an enslaved person could be displaced again at any time, regardless of any bonds of blood or affection s/he may have formed. "...Captive persons were forced into patterns of dispersal, beginning with the Trade itself, into the horizontal relatedness of language groups, discourse formations, bloodlines, names and properties by the legal arrangements of enslavement"(Spillers 75). The perpetual threat of displacement and disconnection is manifest in any number of forms, none of which support or foster long- 
term relationships. As historian Bernard Bell reminds us, "Unlike the first white immigrants and indentured servants, the Africans were the only group to be systematically deprived of their Old World cultural links and social support systems in order to transform them into slaves for life"(7). The type of forced displacement and isolation from community that was foundational to slavery is both part of the instrumentality of atrocity and a chronic symptom of slavery's lingering effects. In context of Beloved, the effects of this perpetual displacement and its attending trauma manifest in Sethe and Denver's isolation, in Paul D's wandering feet, in Baby Sugg's eventual bitterness over the "nastiness of life," in the conspicuous absence of Halle and his sons-all of these locate disconnections that have dire consequences for both individual characters and the community as a whole.

In tracing these disconnections, in the practice of slavery as a whole and in the novel specifically, the primary fractures occur in context of kinship and ancestry. It is impossible to overestimate the importance of ancestry and kinship in constructing African identity. Discovering how slavery impacts kinship structures via family constellation is key in understanding the devastating effects that slavery had on the African subjectivity. African pre-colonial slave practices bear close examination here. Unlike the Transatlantic trade in its early stages, the internal African slave trade was primarily in females. Women were traditionally employed as agricultural labor in African societies that were largely or wholly dependent upon agriculture for its wealth. "Since material development in most West African societies was based upon agricultural activity it followed that production and productivity expansion necessitated the aggressive integration and engagement of women slaves" (Beckles 5). Once entered into 
slavery, an African woman was ripped from her family structure and was essentially kinless, with no claim to anyone's aid or recognition, cut off from support or inheritance. Any children born to her were thereby deracinated, denied kinship rights and transferred into the free labor pool. Ironically, this "kinlessness” becomes “... a useful point of contemplation... of the African female's reproductive uses within the diasporic enterprise of enslavement and the genetic reproduction of the enslaved" (Spillers 74). The enslaved woman became, according to Beckles, the "principal productive agent" in the West African economy. Therefore considerable pressure was exerted to keep slave women enslaved and to "alienate (free) women for social offenses thereby creating situations that could easily lead to their enslavement" (Beckles 5). Women slaves were the wealth of nations in this regard, providing both exchange and use value through their productive labor, through their support services and through their reproductive capabilities.

Similarly, in the New World discourse of slavery, children "followed the condition of the mother" into enslavement, regardless of paternity. "In effect, under conditions of captivity, the offspring of the female does not 'belong' to the mother, nor is s/he 'related' to the 'owner' though the latter 'possesses' it, and in the African-American sense often fathered it" (Spillers 74). In slavery, familial ties are subject to the turn of economic and managerial forces, or merely the whim of the owner. With kinship thus deconstructed to accommodate displacement and forced mobility, discourses of ancestry and especially motherhood become highly problematized. Over the course of the enterprise, managerial discourses shifted in their valuation of the enslaved woman and her offspring, moving from a mindset that it was cheaper to buy than raise a slave, to one 
where the reproductive capabilities of slaves were calculated as part of the wealth they generated. After the Transatlantic trade itself was abolished, "American slavery was dependent on natural increase of the slave population, and through the use of innumerable incentives, planters made sure that slave women were prolific" (White 31). The economic forces driving this managerial shift added to pressure to wring out the maximum benefits from enslaved women, whether those benefits were market production, support services and infrastructure, or socio-sexual access (which also included providing a new generation of laborers). Here it is important to note that " $(\mathrm{t})$ he United States was more successful in producing slaves by natural increase than any other slave-employing society in the Americas" (Thomas 570). In this manner, enslaved women were further objectified, as numerous proslavery discourses arose to justify the violations visited upon them or to minimize the terrible conditions under which they lived. In addition, any children they had were immediately subsumed into the enslaved labor pool as units of production, and were subject to their own displacements and violations from which their mothers could not protect them.

The chilling ways that reproduction and mothering are calculated into the slavery enterprise are salient in that a reproductive discourse is at the heart of Beloved. It is Paul D who articulates the mechanisms of this discourse, in ruminating on Schoolteacher going after Sethe and her children, even after he "writes off" the Sweet Home men as losses: "He wasn't surprised to learn that they had tracked her down in Cincinnati, because, when he thought about it, her price was greater than his; property that reproduced itself without cost" (228). But it is also Sethe's love for her children, and her desire to secure them from the dehumanizing oppression of Schoolteacher and the 
nephews, that drives her to send her three children to Ohio, then follow herself on foot, nine months pregnant with a back ripped open by a brutal whipping.

Frederick Douglass' fierce indictment of the reproductive discourses within slavery lays the blame for the degradations thus created on the slave-owner's most despicable sins: greed and lust. "The whisper that my master was my father may or may not be true; and, true or false, is of but little consequence to my purpose while the fact remains, in all its glaring odiousness, that slaveholders have ordained, and by law established, that the children of slave women shall in all cases follow the condition of their mothers; and this is done too obviously to administer to their own lusts, and make a gratification of their wicked desire profitable as well as pleasurable; for by this cunning arrangement, the slaveholder, in cases not a few, sustains to his slaves the double relation of master and father" (Douglass 13). Douglass further blasts the managerial practice of breaking family bonds early, so that the enslaved mother and child are early alienated from each other:

"It is a common custom, in the part of Maryland from which I ran away, to part children from their mothers at a very early age...For what this separation is done, I do not know, unless it be to hinder the development of the child's affection for its mother, and to blunt and destroy the natural affection of the mother for the child. This is the inevitable result" (Douglass 13).

In context of trauma, how this practice may affect the enslaved subject's ability or willingness to create relationships in later life can be surmised. This disruption catalyzes the first trauma of enslaved life, and socializes the enslaved child to re-enact this type of 
separation again and again in the course of his/her life. These devastating displacements are what Baby Suggs meant by the "nastiness of life." Such perpetual disruption is reflected macrocosmically in the traumatized individual's isolation from community, and in a traumatized community's isolation from the rest of society.

In discussing the disruption of families and the displacement of kinship structures, the most basic, irreducible unit of family relationship is a mother and her child. In context of slavery, all discourses related to reproduction and mothering become highly problematized, because the practice of slavery, ironically, disrupts both of these things even though it requires both to further its enterprise. Not only did enslaved women give birth to the next generation of free labor, they provided care and nurturance to their white owners' children. The Mammy myth—that of an enslaved woman "who could do anything, and do it better than anyone else" and whose competence in domestic matters and loyalty made her "the premier house servant and all others were her subordinates" (White 47)—is so heavily iconized in American popular culture that it demands a more rigorous examination. It is true that many enslaved women were engaged as domestic help, which included acting as caregivers for white children. "Mammy's" privileged position vis a vis both other slaves and her white "family" is logical in light of the reality that "house service was less physically demanding than field work... (in addition) house women could expect to eat better, dress better, and get better medical attention than field women, if only because they were nearer to the master and mistress, not to mention nearer to the kitchen and potential hand-me-downs" (White 50). But it also true that many enslaved children were raised by their white mistresses. As historian Deborah White writes: "White women also played a role in slave child care, and while a legend 
has been built around the black nurses who helped raise white children, the role that white women played in raising slave children has largely been ignored" (53). Balancing these facts leads one to see the informing principle of disrupted mothering in slavery is surrogacy. The disruption of mother-child bond and the continual displacement due to market forces manifests as any number of mother surrogates raising enslaved children.

Behind the phenomenology of displacement and surrogacy, the experience of motherhood in slavery is one of loss, bereavement and grief. In Beloved many of the varying discourses of motherhood are explicated in Baby's and Sethe's narratives. Baby Suggs' narrative locates the material and emotional bereavement of disrupted, enslaved motherhood in that her life experiences represent a full range of the sexual and reproductive discourses within the slavery enterprise:

“...in all of Baby's life, as well as Sethe's, men and women were moved around like checkers. Anybody Baby Suggs knew, let alone loved, who hadn't run off or been hanged, got rented out, loaned out, bought up, brought back, stored up, mortgaged, won, stolen, or seized. So Baby Suggs' eight children had six fathers. What she called the nastiness of life was the shock she received upon learning that nobody stopped playing checkers just because the pieces included her children. Halle she was able to keep the longest. Twenty years. A life time. Given to her, no doubt to make up for hearing that her two girls, neither of whom had their adult teeth, were sold and gone and she had not been able to wave goodbye. To make up for coupling with a straw boss for four 
months in exchange for keeping her third child, a boy, with heronly to have him traded for lumber in the spring of the following year and to find herself pregnant by the man who promised not to and did. That child she could not love and the rest she would not" (23).

Baby's narrative centers on these lost children and the circumstances of their loss. This loss, like the other traumas of slavery, is on-going, as years after her children are sold or chased off, she cannot help but go over the tiny details she does remember of them as children, as she wonders in vain about the adults they became. In speculating on why Halle never made it to 124 Bluestone Road, she considers:

"The last of her children, whom she had barely glanced at when he was born because it wasn't worth the trouble to try and learn features you would never see change into adulthood anyway. Seven times she had done that: held a little foot; examined fat fingertips with her own-fingers she never saw become the male or female hands that a mother would recognize anywhere. She didn't know to this day what their permanent teeth looked like; or how they held their heads when they walked...Four girls, and the last time she saw them there was no hair under their arms" (139). Her relief and gratitude in receiving her grandchildren out of slavery at 124 is palpable. Although her experience of motherhood had been rife with violence, violation and grief, the liberation of Halle's children from the horror that Sweet Home had become under Schoolteacher's management holds out a promise that despite everything, perhaps at last 
her family can be reunited in freedom and safety. It is an elusive, and ultimately false, promise, but the miracle of seeing her grandchildren out of slavery is undeniable. It is an unexpected gift that in her old age, that she should know and live with her grandchildren, and she chides Sethe not to take this for granted:

"You lucky. You got three left. Three pulling at your skirts and just one raising hell from the other side. Be thankful, why don't you? I had eight. Every one of them gone away from me. Four taken, four chased, and all, I expect, worrying somebody's house into evil" (5).

As horrific as Sethe's past has been, she is unusual in that all of her children were conceived consensually with her husband, and that she managed to get all of them out of slavery. To have lost her daughter is tragic, but it is an iteration of any number of lost children who were sold away from their mothers or killed outright. Baby's experiences of losing one child after another are far more typical of motherhood in the enslavement milieu.

If Baby Suggs' narrative gives voice to the grieving enslaved mother, Sethe represents both the displaced mother and the lost daughter. It is as if she is giving voice to the absent narratives of any of Baby's daughters. Baby admonishes her to be grateful that her children were all conceived in love with one man, an unusual case given the typical enslavement scenario of sexual violence and enforced fertility, but as the novel opens, Sethe's first daughter is eighteen years dead, her two sons have run off due to the ghost's violence, and only Denver remains. These displacements, so crushing in the face of the optimism which marked Sethe's first twenty-eight days at 124, are echoes of her 
own displacement from her biological mother, known only as "Ma'am." The absent narratives mirror the familial displacements: Baby longs for her absent daughters, Sethe for her absent mother.

Although she finds a surrogate mother in Baby, Sethe can barely recall her own Ma'am, until Beloved begins asking for stories: "I didn't see her but a few times out in the field and once when she was working indigo" (Morrison 60). Part of Beloved's healing function is revealed as her desire for stories of Sethe's life initiates the resurfacing of memories of Ma'am and Nan. It is Nan, Sethe's first surrogate mother, who tells Sethe the life story of her absent mother, in "different words... What Nan told her she had forgotten, along with the language she told it in. The same language her ma'am spoke, and which would never come back again" (62). In reaccessing this memory, she realizes that her mother came from "the sea" (Africa via the Middle Passage), and that she herself was not the product of sexual violence, but rather conceived by two consenting African parents:

"She threw them all away but you...Without names, she threw them. You she gave the name of the black man. She put her arms around him. The others she did not put her arms around" (62).

Despite her alienation from her mother, Sethe replicates the most significant aspects of her mother's life vis a vis ancestry: she has children that are conceived in love, and can claim even the tiniest inheritance from her father in her name.

In the case of Baby and Sethe, what we see in each narrative is a matrilineage being disrupted. Baby loses her daughters, Sethe loses her mother. In both cases, substitutes and surrogates manifest to provide care and continuity to the next generation. 
These surrogates act, as much as possible, to fill in the gaps that slavery's displacement and violence give rise too. Thus it is Nan who tells Sethe her mother's story, giving her important clues to her own identity via her African ancestry. There has been tendency in racial discourse, at least since Senator Daniel Moynihan's report on "The Negro Family" (1965), to view the disruptions to which the Black American kinship structures are vulnerable as irredeemably pathologizing, and Black Americans as somehow inherently dysfunctional. It is important to note that the African concept of kinship is not merely linear, but accounts for vast networks of interrelated individuals woven together by their shared histories and their commitment to raising the next generation. Slavery may have made the maternal substitutions a bitter necessity, but it accomplished the important goals of kinship by raising up offspring capable of reproducing themselves, who carry forward the stories and memories of the ancestors, not matter how fleeting.

Denver is emblematic of the traumatizing effects of displacement and isolation, but she also symbolizes an evolution towards greater familial stability in the postEmancipation generation. Denver's life and psyche are marred by slavery's legacy, though she never lived as a slave. Lonely, isolated, agoraphobic, her life is literally bound by the Misery and its consequences. Despite losing any contact with the community, her father, both her brothers and eventually her grandmother, Denver still has something none of the other characters have: prolonged access to both her paternal and maternal line. Unlike the other characters, she grows up with her mother and paternal grandmother, and is still with them even as she is becoming an adult.

Furthermore, Denver invokes the absent Halle and fills in the disruption in the chain of ancestry caused by his absence. She is repeatedly described as "her father's 
daughter", possessed of his "sweet face" and practical manner. Much as Baby was "allowed" to keep Halle with her for an unheard of twenty years, Sethe has been allowed the solace of keeping her youngest child with her, and Denver mirrors her father's experience of remaining by his mother and sacrificing for her welfare. These things sustain her as she takes those crucial and frightening steps off the porch to get help for Sethe. When Lady Jones sees her again after more than a decade, she thinks:

"Everybody's child was in that face" (246). Denver is metonymic of so many children, not lost as Beloved was lost, but lost nonetheless. She is every child sold off from his/her mother. Since she represents a more unified subjectivity—being the only character who has the benefit of both sides of her ancestry, the maternal and the paternal—she can also be the agent who brings in the potential for and means of healing.

Although it is Denver who initiates the healing by asking for help, it is the community of Black women from whom she asks it that really makes the healing possible. As Herman states, reconnection to the community is the final step in the trajectory of healing. In the case of Sethe's healing, reconnecting with community is even more important, and even more difficult, because the Black community bears complicity in the Misery. The community's part in Sethe's narrative is a painful one, and one that creates a rift so great it requires movement on both sides to repair. As much as Sethe needs her healing and redemption from Beloved's murder to be located within the context of the community from which she has been isolated, so does the community require this rupture to be resolved for themselves to be redeemed.

To understand the significance of the rupture between Sethe and the rest of the community, one must examine those twenty-eight days of true freedom, between 
enslavement at Sweet Home and enslavement to the past. The house at 124 Bluestone Road to which Sethe first stumbles is a radically different place than the house the reader finds as the novel opens. Back then, 124 was a vibrant, living place, the center of the free Black community in Cincinnati, a stop on the Underground Railroad, a hub of Abolitionist optimism and purposeful action:

"Before 124 and everybody in it had closed down, veiled over and shut away, before it had become the plaything of spirits and the home of the chafed, 124 had been a cheerful, buzzing house where Baby Suggs, holy, loved, cautioned, fed, chastised and soothed, where not one but two pots simmered on the stove; where the lamp burned all night long. Strangers rested there while children tried on their shoes. Messages were left there, for whoever needed them was sure to stop in one day soon" (86-87).

When Sethe arrives at 124, the house is the center of a fragile web of support and interdependence by which the vulnerable free Black population holds on. Baby Suggs is the spiritual heart of this community, preaching an unorthodox Gospel of embodied subjectivity that moves the congregation to claim their free selves. This is one of the most important services 124 and the community surrounding it provides the ex-slaves who attempt to build new lives in Cincinnati: they model ways of living in a newly free body. "One taught her the alphabet; another a stitch. All taught her how it felt to wake up at dawn and decide what to do with the day" (95). The example of this large, vital community, so passionately engaged with issues of race and sovereignty, provides Sethe 
with a very brief instruction in how to conduct herself as a free being and gives promise of a life she could possibly have. Among her many regrets is what her actions cost Baby:

"No more lamp all night long, or neighbors dropping by. No low conversations after supper. No more watched children playing in the shoes of strangers. Baby Suggs, holy, believed she had lied.

There was no grace — real or imaginary—and no sunlit dance in a Clearing could change that" (89).

The Misery isolates the women and children at 124, and Baby Suggs loses the community that has acted as a compensation for the deprivations of her life and as the arena in which the quasi-divine powers of her heart are made manifest.

For the core message of Baby's Sermon on the Flat Rock is "that the only grace they could have was the grace they could imagine" (88). The community's complicity in the Misery is the failure of their imagination, their inability to perceive and receive divine grace. Soon after Sethe's arrival, Stamp Paid brings two buckets of berries to Baby's house to celebrate their arrival. This balloons into a miraculous feast of such abundance that the rest of the community becomes envious: "It made them furious. They swallowed baking soda, the morning after, to calm the stomach violence caused by the bounty, the reckless generosity on display at $124 "(137)$. The Black community that she served stands aside and does not alert them or try to help when Schoolteacher finally tracks Sethe and her children down: "...that explained why nobody ran on ahead; why nobody sent a fleetfooted son to cut 'cross a field as soon as they saw the four horses in town hitched for watering while the riders asked questions" (157). The idea that abundance and grace of that intensity could be available is too challenging a thought to give comfort to the 
struggling, formerly enslaved community. It is a grace they cannot imagine and therefore cannot have: a tragedy which precipitates the more visceral calamity of Beloved's murder. As Douglass, Harriet Jacobs and Sethe can attest: the creation of a free subjectivity takes time, even after physical liberation is achieved. The failure of the imagination of the townspeople is a direct effect of their traumatized state. Their own liberated subjectivities are not strong enough to counter generations of marginalization and self-loathing. They cannot imagine being worthy of the grace bestowed upon Baby Suggs' family and they withhold their help to put them back in their place.

This failure of the imagination, and the silence that engulfs Sethe and her family as a result, have terrible consequences for both the family, and the community in which these silences occur. As Israeli psychologist Dan Bar-On queries: "What has been transmitted, intergenerationally, or reconstructed from those silenced facts, within families of perpetrators, victims, rescuers and bystanders? How can one actually reestablish a social contract based on trust after such events have disrupted the social network, breaking it into these categories" (Bar-On 4)? Infuriated further by the pride she evinces after the crime, Sethe, Baby Suggs and the children are left alone and friendless to contend with the harsh realities of life and the angry, revengeful ghost in their home. In this manner the wounds of Beloved's murder go beyond the victim and the perpetrator. Her murder is situated in the grievous fracture between Baby Suggs, holy, and her congregation that persists years after Baby's death in Sethe and Denver's continuing isolation. It is the heavy weight that burdens everyone involved. If Sethe regrets costing Baby Suggs her congregation, vocation and final shred of hope, the community that indulges in righteous anger against Sethe's pride pays a heavy price for 
the moral high ground. While the community appears to flourish, and the networks of interdependence and mutual aid still operate, the center of the community is gone, no longer involved in living and the present but bound up in death and the painful past. In addition to absorbing the projections of the rest of the town-projections of fear, loathing, judgment and contempt -124 is a reminder of a debt that the townspeople can never repay: the debt of their complicity in the Misery, which implicates them all as perpetrators of the same violence and violation they fled. Sethe's pride allows the townspeople to withhold sympathy from her and keeps them safe from feeling their own fair potions of guilt and shame.

When Denver leaves 124 for the first time in years in order to get help, the community of women who turned their backs on her family responds with gifts of food as they share with the young woman their own memories of Baby Suggs and 124: "Maybe they were sorry for the years of their own disdain. Maybe they were just nice people who could only hold meanness toward each other for just so long and when trouble rode bareback among, quickly, easily, they did what they could to trip him up (249)." These women confront the ghost and keep Sethe from murdering their white benefactor, Mr. Bodwin, in a confused panic, thereby releasing Beloved and laying her to rest, at the same time that the enmity between 124 and the rest of the community is finally resolved. Only through the act of communally facing down the past, can the ghost be laid to rest and the family be healed. This healing manifests in Sethe's ability to name her loss to Paul D without spinning a circuitous rationale ("She was my best thing") and in Paul's affirmation of Sethe's humanity (which he questioned at the time of her disclosure by reminding her how many feet she had) in her subjectivity: "”You your best thing, Sethe. 
You are."' (273). It manifests in the continuation of the ancestral line and the formation of stronger, less vulnerable families in the future, alluded to in Nelson's courting of Denver. It is a potential for healing that persists even though Morrison's last words on the subject echo the dismemberment and silence of stories that cannot be told, because one has yet to ask for them.

This healing is made manifest in every iteration of this story; because every generation, figuratively and literally, carries the tale forward. This is the Africanist imperative whereby the people and the stories perpetuate themselves and each other; the drive which makes Beloved as insistent to conceive a child with Paul as she is to remember herself via her mother's memories of rhinestone earbobs and baby spit; which made Sixo whisper to the seventeen-mile woman and shout "Seven-O" as his final "fuck you" to Schoolteacher. The labor, the flesh may be consumed, but each iteration of the story and each generation of descendants that know it, perpetuates these two lines through time and space into the future. These two lines are not merely parallel, but are bound to and circle around each other like the helixes of DNA, and like strands of DNA, they carry each other forward, informing and performing each other, healing the wounds of the collective past. 


\section{CONCLUDING THOUGHTS: BRINGING THE STORY FORWARD}

The story of Africans in America is, at its heart, the story of a journey, and like many journeys and the tales about them, this story ends where it started, with huge movements of human will, invention and empire coming to ground in tiny, individual moments of agency, resistance and remembrance. My experience of this thesis has likewise been a journey which led where I could not predict, but that is now at its end. And therefore it seems appropriate to end at the beginning, with the first spark of insight that inspired me to do this study, to find the opportunities for selfexpression and transcendence in environments of the most crushing dehumanization, to alchemically transform suffering into knowledge, healing and reconnection. I saw this possibility manifest in the literature of the Holocaust, and I wondered if the same dynamic would manifest in African American literature. It was encountering the Hungarian novelist Imre Kertesz in my first year of graduate studies that gave me this spark.

The centrality of the Holocaust in the work of Nobel laureate Imre Kertesz is unquestionable. If the evidence of his oeuvre does not suffice, Kertesz affirms this primacy in interviews, lectures and in his Nobel address, when he reveals, "When I am thinking about a new novel, I always think of Auschwitz" (www.nobelprize.org). Seen through the eyes of this survivor of one of the greatest crimes against humanity ever committed, the Holocaust stands as more than a horrific historical event, or as mere content for literary fiction. Rather, the Holocaust is a catalyst to what Kertesz calls an existential discovery and poses a moral challenge to Western civilization. $\mathrm{He}$ elaborates on this point further in his Nobel address:"What I discovered in Auschwitz 
is the human condition, the end point of a great adventure, where the European traveler arrived after his two-thousand year moral and cultural history." Kertesz's optimism raises several questions: can anything be salvaged out of the atrocities that negated thousands of years of the Humanist tradition? Despite the venality and sadism that engineered, executed and abetted the Final Solution, for Kertesz salvation is found in the irresistible moral force that atrocity can generate: "At the price of immeasurable suffering, the Holocaust has opened up immeasurable knowledge, and thus, immeasurable moral reservoir" (Forgasc 9). In this way, every story he tells is one story: the narrative of a staggering trauma inflicted upon him as a young man. Every story he tells is his attempt to pass down this narrative and its accompanying moral gnosis to the next generation. In bringing the story forward to new generations, the knowledge shared becomes the mechanism by which atrocity can transcend and transform suffering into wisdom and compassion.

I bring up Kertesz here to invoke and interrogate the moral imperatives of literature as the Humanist's sacred tool against crushing oppression and violence. Though he speaks of atrocities committed a hundred years later, and in a historical and political milieu that is radically divergent from that of Trans-Atlantic enslavement, Kertesz's explication of the Humanist grace at the end of unimaginable atrocity speaks eloquently of the power of the story in healing the psychic wounds of trauma. To tell the truth of one's experience, to assert one's subjectivity in the face of negation and erasure, is profoundly important not only for the traumatized individual but for traumatized communities as well. This moral force can never act 
fully as a corrective to the atrocity in question, but it can open opportunities for healing, reconnection and protection.

In African-American literature, there is a similar recuperative aspect of speaking truth to power that is always present. This is not to compare or contrast the vast systems of the Final Solution to Transatlantic slavery. Such an exercise is futile at best. But Kertesz's own words, regarding the "great adventure" of European humanism arriving at its end point in Auschwitz, beg several questions in context of slavery. The Transatlantic slave trade was an atrocity perpetrated over hundreds of years, but it did not signal the end of European Humanism: it fueled it. How are we to read the grand philosophical oxymoron embedded in the Age of Reason, when the drive for philosophers to explicitly state the innate rights of all humans was concurrent with an imperialist drive to deny those same rights to certain groups of people? The pressures of industrialization and empire demanded an ideology of racial inferiority to justify the excesses of slavery. The economic pressures and allurements of imperialist expansion demanded the agricultural products of free labor (cotton, coffee, corn, etc) to support a rapidly expanding industrial consumer base, and to supply and feed the growing urban proletariat engaged in manufacturing. Upon the foundations of cheap labor and goods, was empire fostered, and the class structures that held this hegemony in place were justified and upheld as natural law and God's plan. Empire demanded an ideology and a rhetorical arena where humanity was not accorded to all humans. To assert one's humanity in light of this ideology, and to speak the truth of one's abuse despite the rampant justifications for it, was a revolutionary act, and a recuperative one. 
African American literature finds its origin in these acts of literary defiance and self-definition. According to Christopher Mulvey, African American literature finds its provenance in two distinct genres: the narrative of enslavement and the (white) popular novel, but he states that as a genre it "owes its distinctiveness to the slave narrative (Graham 20)" because here authors were "work(ing) through a pattern of realization, resistance, flight, survival and deliverance focusing on actions and themes that were not commonplaces of the Victorian novel" (Graham 18). While not commonplaces of the Victorian novel, these tropes are recurrent themes within the recuperative narrative discourses found in historical enslavement narratives that persist into modern fictional texts such as Beloved. It is no coincidence that these tropes-realization, resistance, flight, survival, deliverance-are also commonplaces found in the recuperative texts of trauma survivors, as part of the therapeutic progression of those psychological discourses. These tropes manifest in actions of self-definition, of agency and of resistance.

I have shown how the personal narrative is of primary importance in both the creation of a liberated Black subjectivity and in the reclamation of an integrated self subsequent to the shattering effects of trauma. Through a close reading of Beloved. I have also demonstrated that the tropes common to both the historical slave narrative and therapeutic discourses of trauma recovery are present in the action and plot of Morrison's novel, helping to bridge these two divergent discourses. In explicating the recuperative function of the narrative in both of these contexts, the "moral reservoir" of which Kertsz speaks becomes more explicit and the moral imperatives of this type of literary discourse become sharper. This history is our history as Americans. These 
stories are ours, regardless of when or how our ancestors arrived at these shores. And as these stories are ours, so too is the obligation to remember, to sing praise and to pass the story on to our descendants. Unable to change the past, we acknowledge how we are shaped by it, and how we shape our own understanding of it by engaging with it, in honesty and compassion. We are confronted, not by the resolutions of the past, but with challenges to the future: to remember those who are gone, to restore their stories to the chain of history and memory, to recoup if possible those languages which would never come back again.

As Herman says, in the milieu of atrocity, the lines between perpetrators, victims and witnesses lose their sharpness. Part of the moral reservoir Kertesz discusses is the acceptance of an obligation, by subsequent generations, to bring these stories forward. By bearing witness to the events and hearing the narratives, the moral challenge becomes for us to bring this knowledge forward, this painful knowledge of our species, of our infinite capacity for cruelty and our endless search for redemption. The ultimate acknowledgement of the sacrifices of the enslaved is our acceptance of that obligation to remember them and their experiences, and to honor their labor which shaped our world. Those who were lost in Middle Passage, and those who were lost in the New World, have passed out of history into anonymity. Restoring them and their stories to the chain of history requires bringing forward that story and that obligation to the next generation. 


\section{WORKS CITED}

Andrews, William L. "The Representation of Slavery and the Rise of Afro-American Literary Realism." Slavery and the Literary Imagination. MacDowell, Deborah E. and Arnold Rampersad, eds. Baltimore: Johns Hopkins University Press, 1989

Andrews, William L. To Tell A Free Story: The First Century of Afro-American Autobiography, 1760-1865. Chicago: University of Illinois, 1988.

Bar-On, Dan. The Indescribable and Undiscussable: Reconstructing Human Discourse after Trauma._Budapest: Central European University Press, 1999.

Bell, Bernard W. The Afro-American Novel and Its Traditions. Amherst, MA: University of Massachusetts Press, 1987.

Biobibliographical Note on Imre Kertesz.

http://nobelprize.org/nobel_prizes/literature/laureates/2002/kertesz-lecture-e.html

Carabi, Angels. “Toni Morrison.” Belles Lettres: A Review of Books by Women 9.(1994)

Carby, Hazel "Ideologies of Black Folk: The Historical Novel of Slavery" Slavery and the Literary Imagination. MacDowell, Deborah E. and Arnold Rampersad, eds. Baltimore: Johns Hopkins University Press, 1989

Douglass, Frederick. . Narrative of the Life of Frederick Douglass, an American Slave, Written by Himself. William L. Andrews and William S. McFeely, eds. New York: W.W. Norton Publishing, 1997

DuBois, W.E.B. The Souls of Black Folk. New York: Alfred A. Knopf, 1903.

Graham, Maryemma. The Cambridge Companion to the African American Novel. Cambridge, UK: Cambridge University Press, 2004

Forgacs, Eva. Dictionary of Literary Biography Yearbook: 2002. Farmington Hills, MI: The Gale Group, 2003.

Heinze, Denise. The Dilemma of "Double-Consciousness": Toni Morrison's Novels. Athens, GA: University of Georgia Press, 1993.

Herman, Judith Lewis. Trauma and Recovery. New York: Basic Books, 1992. 
Jacobs, Harriet. Incidents in the Life of a Slave Girl. Nellie Y. MacKay and Frances Smith Foster, eds. New York: W.W. Norton \& Co., 2001.

Kertesz, Imre. "Eureka!" Nobel Lecture. Nobel Prize in Literature Award Ceremony. Stockholm, Sweden. 2 December. 2002.

http://nobelprize.org/nobel_prizes/literature/laureates/2002/kertesz-lecture-e.html

Lynch, Patricia Ann. African Mythology A to Z. New York: Facts on File, Inc, 2004.

MacDowell, Deborah. "In the First Place: Making Frederick Douglass and the AfroAmerican Narrative Tradition." Narrative of the Life of Frederick

Douglass, an American Slave, Written by Himself: authoritative text, contexts and criticism. Frederick Douglass. William L. Andrews and William S. McFeely, eds. New York: W.W. Norton Publishing, 1997.

Mbalia, Doreatha Drummond. Toni Morrison's Developing Class Consciousness. Selinsgrove,PA: Susquehanna University Press, 1991.

McFeely, William S. "The Writing of the Narrative" Narrative of the Life of Frederick Douglass, an American Slave, Written by Himself: authoritative text, contexts and criticism. Frederick Douglass. William L. Andrews and William S. McFeely, eds. New York: W.W. Norton Publishing, 1997.

Mobley, Marilyn Sanders. “A Different Remembering: Memory, History and Meaning in Toni Morrison's Beloved" in Toni Morrison: Critical Essays. Harold Bloom, ed. Broomall, PA: Chelsea House, 2000.

Morrison, Toni. Beloved. New York: Alfred A. Knopf, 1987.

Morrison, Toni. Playing in the Dark. Cambridge: Harvard University Press, 1992.

Mulvey, Christopher. "Freeing the voice, Creating the self: the novel and slavery" in the The Cambridge Companion to the African American Novel. Cambridge, UK: Cambridge University Press, 2004

O'Brien, L. Stephen. Traumatic Events and Mental Health._Cambridge, UK: Cambridge University Press, 1998.

Page, Philip. Dangerous Freedom. Jackson, MS: University Press of Mississippi, 1995. 
Ripley, Peter "The Autobiographical Writings of Frederick Douglass." Narrative Of the Life of Frederick Douglass, an American Slave, Written by Himself: authoritative text, contexts and criticism. Frederick Douglass. William L. Andrews and William S. McFeely, eds. New York: W.W. Norton Publishing, 1997.

Spillers, Hortense. "Mama's baby, Daddy's Maybe: An American Grammar Book". Diacritics, Summer 1987.

Thomas, Hugh. The Slave Trade. New York: Simon \& Schuster, 1997.

White, Deborah Gray. Ar'n't I a Woman: Female Slaves in the Plantation South. New York: W.W. Norton \& Co., 1985.

Wilson, John P. Trauma, Transformation and Healing. New York: Brunner/Mazel, 1989. 